FACULDADE DE LETRAS DA UNIVERSIDADE DE COIMBRA INSTITUTO DE HISTÓRIA ECONÓMICA E SOCIAL

\title{
A População de Mira e a Desamortização dos Baldios na segunda metade do séc. XIX
}

POR

MARIA MARGARIDA SOBRAL NETO

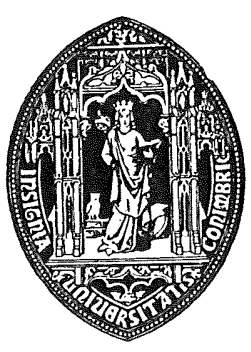

COIM B R A -1982 
FACULDADE DE LETRAS DA UNIVERSIDADE DE COIMBRA INSTITUTO DE HISTÓRIA ECONÓMICA E SOCIAL

\title{
A População de Mira e a Desamortização dos Baldios na segunda metade do séc. XIX
}

\author{
POR \\ MARIA MARGARIDA SOBRAL NETO
}

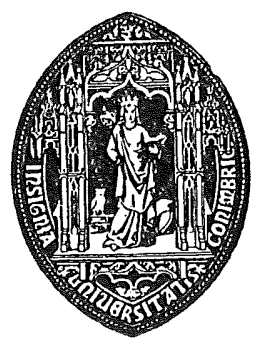

C O I M B R - 1982 


\section{A POPULAÇÃO DE MIRA E A DESAMORTIZAÇÃO DOS BALDIOS NA SEGUNDA METADE DO SÉC. XIX *}

1 - Na sequência de um processo tendente à privatização dos baldios, que se começara a desenhar nos inícios do séc. XVII (1), em 28 de Agosto de 1869 era publicada uma lei que determinava a desamortização desses terrenos tanto a nível municipal como paroquial, exceptuando, apenas, aqueles que eram indispensáveis ao logradouro comum.

Villa Nova Portugal na sua Memória «sobre a cultura dos terrenos baldios que ha no Termo da villa de Ourém», publicada em 1790, define assim baldios: «Aquelles terrenos, que ficaraõ pertencendo aos

* A análise de 2 maços de documentos, que, com a referência «Baldios 1862-63, 1873-74 e 1885-88» e «Baldios 1884-1894», se encontram no Arquivo da Universidade de Coimbra, no fundo originário do governo civil, levou-nos a projectar um estudo sobre a função económica e social dos baldios, na segunda metade do séc. XIX, perspectivada através da atitude dos seus usufruidores perante a lei de desamortização de 28 de Agosto de 1869.

Dada a impossibilidade de, desde já, reunir toda a documentação que permita um estudo a nível do actual distrito de Coimbra e como possuímos um núcleo razoável para o concelho de Mira, decidimos publicar um artigo referente a este concelho.

Apresentamos desde já os nossos agradecimentos à Câmara de Mira pela colaboração prestada na elaboração deste trabalho e congratulamo-nos pelo interesse manifestado pela história da sua terra.

(1) As Ordenações Filipinas, em 1603, possibilitavam a passagem dos baldios a bens do concelho, facilitando assim a sua apropriação individual. Cfr. Armando de Castro, Baldios, in «Dicionário de História de Portugal», Lisboa, 1971, vol. I, p. 280 e Francisco José Velozo, Baldios, maninhos e exploração silvo-pastoril em comum, Braga, 1953, p. 26. 
moradores do Termo, e no seu dominio em commum, assim como os allodiaes no seu domínio em particular; e que antigamente se explicárão pela palavra logradouros do Povo» (2). $\mathrm{O}$ autor apresenta o baldio como uma categoria jurídica à parte, distinguindo-o claramente dos maninhos e dos bens dos concelhos.

Este claro e correcto entendimento constitui, no entanto, uma excepção (3). Com efeito, se o direito de os povos usufruirem os baldios aparece bem explícito ao longo do tempo, já o mesmo não acontece em relação ao direito de propriedade. O esquecimento de que os baldios pertenciam aos «moradores do Termo» que tinham o «domínio em commum» levou proprietários a apoderarem-se de alguns desses terrenos e câmaras municipais a assumirem a administração dos baldios como se de bens do concelho se tratasse, utilizando-os ou alienando-os, nem sempre de acordo com os interesses de todos os seus legítimos possuidores e não simples beneficiários do usufruto (4).

Esta prática acabava por ter a cobertura de uma legislação que não definia com clareza e sem ambiguidades a natureza jurídica desta forma de propriedade $(5)$.

A perda de individualidade e consequente confusão com outras formas de propriedade a cujo usufruto a população podia ter acesso - caso dos bens do concelho - que o baldio sofre ao longo do tempo,

(2) Thomaz Antonio de Villa Nova Portugal, Memoria sobre a cultura dos terrenos baldios que ha no termo da villa de Ourem, in «Memorias Economicas da Academia [...]», tomo II, Lisboa, 1790, p. 414.

(3) Acerca deste assunto vide: Rogério Soares, Sobre os baldios, Coimbra, 1968 (Sep. da «Revista de Direito e de Estudos Sociais», ano XIV, n.os 3-4).

(4) O alvará de 23 de Julho de 1766 referia o abuso praticado pelos «vereadores, e mais Pessoas, que costumam andar nas governanças» nos aforamentos de baldios repartindo-os entre si, seus parentes e amigos e determinava que essas pessoas não podiam aforar baldios (António Delgado da Silva, Collecção da Legislação Portugueza desde a ultima compilação das Ordenações, vol. II (1763-1774), Lisboa, 1829, pp. 265-267). Sobre apropriação abusiva de baldios ver: Rogério Soares, op. cit.; Francisco José Velozo, op. cit.; Armando de Castro, op. cit.; Reconhecimento dos Baldios do Continente, Junta de Colonização Interna, vol. I, Lisboa, 1939.

(5) «A partir do reinado de D. José é frequente a confusão intencional, na linguagem legislativa, entre a propriedade comunal e a propriedade corporativa, atribuindo-se os baldios à pessoa moral do concelho ou freguesia» (Marcelo Caetano, Manual de Direito Administrativo, 8. ${ }^{a}$ ed., Lisboa, 1969, tomo II, p. 960). Ainda sobre o assunto e nomeadamente sobre a forma imprecisa como o Código Civil de 1867 define «coisas comuns» vide Rogério Soares, op. cit.. 
está intrinsecamente ligada às transformações económicas e sociais. Nascendo para servir de complemento à actividade agro-pecuária em economias tradicionalmente designadas de subsistência, ele foi desaparecendo à medida que se introduziam relações capitalistas na agricultura, cujo evoluir exigia a supressão de formas colectivas de propriedade (6).

É a partir do séc. XVIII que, em Portugal, se verifica de uma forma mais sistemática a apropriação individual dos baldios.

Apesar de haver terrenos destes, cuja fruição se concretizava na exploração agrícola de parcelas periodicamente distribuídas, o baldio era, em regra, o terreno inculto cuja vegetação espontânea se utilizava para pastagem de gado, lenhas, estrumes ou madeira. Constituindo, portanto, uma parte considerável da extensa área inculta que no «Antigo Regime» caracterizava a paisagem rural portuguesa (7), o baldio começou a ser visto pelos pensadores da nossa economia como um índice e factor de atraso da agricultura. Consideravam que eram terrenos subaproveitados, pois, para além de constituirem, em alguns casos, áreas potencialmente agricultáveis, cumpriam deficientemente a sua tradicional função de campos de pastagem e de fornecimento de lenhas, estrumes e madeiras devido ao facto de não serem lavrados $\left.{ }^{8}\right)$.

(6) Ver Armando de Castro, Traços Gerais da Evolução Económico-Social Portuguesa no século XIX, in «Ensaios de História Económica e Social», Vila Nova de Famalicão, 1967, pp. 147-150.

(7) Gerardo Pery avaliava a área de terrenos incultos em 4.029 .500 ha. (Gerardo Pery, Geografia e Estatistica de Portugal e Colónias, Lisboa, 1875, p. 109).

(8) Referindo-se à Comarca de Penafiel, Província do Minho, escreveu o 2..$^{\circ}$ Visconde de Balsemão: «Ha nesta comarca excellentes baldios por rotear, taes são os seguintes: no termo da cidade ha alguns pedidos, a que se oppõem os povos, por cauza das pastagens; e mesmo aquelles que, não sendo proprietários, tem rebanhos que pascentão e se nutrem á custa dos outros. Esta mal intendida preocupação, em que estão sobre pastos comuns, faz um maior mal á agricultura do que se não pença e, apezar de estar demonstrada a sua inutilidade por bastantes escriptores praticos, presiste na sua rotina, bem damnoza ao Estado». (Memória sobre a Província do Minho pelo 2. ${ }^{\circ}$ Visconde de Balsemão, publicada por José M. Amado Mendes, in «Revista Portuguesa de História», tomo XVIII, 1980, p. 87). Sobre o assunto ver também: José Ignacio da Costa, Memoria Agronomica relativa ao concelho de Chaves, in «Memorias Economicas da Academia [...]», vol. I; Antonio Henriques da Silveira, Racional Discurso sobre a Agricultura e população da Provincia de Alem Tejo, in «Memorias Economicas da Academia [...]», vol. I; Thomaz Antonio de Villa Nova Portugal, op. cit.. 
Mas, se um destes estudiosos, José Ignacio da Costa, propunha novas formas de exploração dos baldios preservando a mesma estrutura de propriedade (9), já Villa Nova Portugal considerava necessária a sua privatização para se obter uma maior e melhor rentabilidade económica, fundamentando o seu parecer no princípio: «a cultura he segundo o direito de propriedade» $\left({ }^{10}\right)$.

Poderíamos citar outros autores que, no séc. XVIII, se pronunciaram a favor do individualismo agrário.

No séc. XIX intensificam-se as posições desfavoráveis à existência de práticas comunitárias. Herculano escreveu: «A existência dos baldios municipais, dos pastos comuns, é um dos mais graves embaraços ao progresso da agricultura entre nós» (11).

Estas opiniões e práticas desfavoráveis aos baldios bem como a outros usos e costumes comunitários enquadram-se num movimento mais vasto que tinha como objectivo a «libertação» da propriedade de todo um conjunto de limitações à sua fruição num sentido absoluto. É nesta linha que surgem as leis de desamortização (12), a extinção do regime de morgadio em 1863 e a supressão do compáscuo pelo Código civil de 1867.

A lei de desamortização de 1869 insere-se, portanto, neste contexto e constitui um marco importante na vida dos baldios, já que é a primeira que tem como objectivo uma desamortização global preservando apenas os indispensáveis ao logradouro comum.

Esta lei constitui, também, uma faceta do esforço de desenvolvimento da agricultura que se regista, com resultados positivos, na segunda metade do séc. XIX e que tem uma das suas expressões no arroteamento de áreas incultas (13).

(9) José Ignacio da Costa, op. cit., pp. 394-396.

(10) T. A. de Villa Nova Portugal, op. cit., p. 419.

(11) Alexandre Herculano, Breves Reflexões sobre Alguns Pontos de Economia Agrícola, in «Opusculos», tomo VII, Lisboa, 1898, p. 33.

(12) Este processo iniciara-se em 1834 com a venda dos bens nacionais. Alarga-se, em 1861, a alguns bens das igrejas e das corporações religiosas e em 1866 a bens dos distritos, municípios, paróquias, casas de misericórdia, hospitais, irmandades, confrarias, recolhimentos e outros estabelecimentos pios ou de beneficência nacionais ou estrangeiros. Na lei de 28 de Agosto de 1869 estavam incluídos também os bens e direitos imobiliários que constituíam os passais dos párocos e pertencentes aos estabelecimentos de instrução pública.

(13) Miriam Halpern Pereira, Livre Câmbio e Desenvolvimento Económico. Portugal na segunda metade do Século XIX, Lisb oa, 1971, cap. II. 
A resolução de problemas financeiros é também um dos objectivos que está subjacente às tentativas feitas pelo governo para execução da lei, objectivo a que não é aliás alheia toda a legislação desamortizadora.

Mas se ao longo da Idade Moderna e Contemporânea se verifica uma progressiva apropriação de baldios, a ela se opôs muitas vezes o povo, principalmente quando essa apropriação revestia uma forma clara de usurpação. Também em 1869 e nos anos subsequentes, o povo reagiu e nem sempre correspondeu ao objectivo de desamortizar certas áreas baldias. É a atitude da população de Mira perante as tentativas de aplicação aos seus baldios da lei já referida que vai ser objecto de análise e reflexão no trabalho que apresentamos.

2- Antes de estudarmos a atitude da população de Mira perante as tentativas de aplicação da lei de desamortização, vamos carrear alguns dados que nos permitam entrever a função económica e social dos baldios.

O concelho de Mira fica situado na Beira Litoral, na sub-região da Gândara. Ocupava na segunda metade do séc. XIX uma área de 9.965 hectares de terreno (14) com uma constituição geológica arenosa.

Uma parte considerável do espaço, que se estendia pela orla litoral e também pelo interior, estava inculto. Esta superfície não agricultada era constituída por baldios municipais.

Ao longo da segunda metade do séc. XIX, a Câmara fomentou a transformação de alguns destes incultos em campos cultivados e arborizados (15). A alienação e subsequente redução à cultura de alguns baldios iniciou-se em 1848 e processou-se através do regime de aforamento em hasta pública (16). Simultaneamente foram arborizados «areais e

(14) Relatório apresentado à Junta Geral do Distrito pela Comissão Distrital em 1874, Coimbra, Imprensa da Universidade, 1874, p. 6.

(15) As areias do litoral teriam já sido arborizadas anteriormente. Em 1924, uma pessoa de 90 anos de idade contava a Manuel Alberto Rei, regente florestal, que, no tempo dos seus pais, os soldados da última invasão francesa haviam destruído pelo corte e pelo fogo as árvores que cobriam esta zona. Este testemunho era comprovado, pelo menos em parte, pelo aparecimento de cepos de pinheiro completamente podres. (Manuel Alberto Rei, Pinhais e Dunas de Mira-Subsidios para a sua história - 1919 a 1924, Figueira da Foz, 1924, p. 9).

(16) No período que decorre de 1848 a 1869 foram aforados prazos nos baldios denominados Gandara do Montalvo, Gandara da Parada, Gandara do Portomar, 
mais baldios». O empenho posto pela Câmara na arborização, sobretudo das zonas do litoral, decorria da necessidade de proteger os terrenos cultivados das areias que os esterilizavam e tinha também como objectivo a criação de riqueza em madeiras, lenhas e estrumes (17).

Apesar das dificuldades de natureza financeira com que a Câmara deparou e que a levaram, algumas vezes, a pedir à população a colaboração nas sementeiras, e inclusivamente o fornecimento de sementes, a arborização prosseguiu. Se, em 1852, se faz referência a um «único pinhal», em 1869 já se tinha semeado penisco nos baldios da Barra, Gandara de Portomar, Gandara da Parada e Montalvo, em 1877 constam dum inventário 10 pinhais e 2 baldios com alguns pinheiros (18). Posteriormente, foram arborizados outros, nomeadamente parte do baldio denominado a Videira e o de Portomar.

Conjugada com a criação de novos espaços produtivos, é também perceptível neste período, mas com mais frequência a partir do terceiro quartel do século XIX, a construção de habitações para pessoas e animais. Nas actas das reuniões da Câmara surgem, frequentemente, pedidos de alinhamento para a construção de casas, palheiros, currais, «obra nova». Este fenómeno deve estar relacionado com o crescimento demográfico e com o enraizamento de um núcleo de população no local denominado Palheiros de Mira, hoje Praia, através da fixação de pessoas do concelho e de fora dele ${ }^{19}$ ).

Esboçado o meio físico, vamos tentar agora apresentar alguns dados sobre as pessoas que aí habitavam e que, laboriosa e engenhosa-

Barra, Ermida, Pinhal do Fidalgo e Arieiro das Cavadas. Em 1869 a câmara recebia foros referentes a 166 prazos (Arquivo Municipal de Mira (= A.M.M.): Autos de aforamento -1847 a 1869 ).

(17) A.M.M.: Livro de Actas (= L.A.), 1858-1866, f. 220v. A arborização das areias do litoral e de outras zonas do interior fazia parte de um projecto de arborização. Ver Decreto do Ministério das Obras Públicas de 21 de Setembro de 1867, in Colleç̧ão Official da Legislação Portugueza, 1867, pp. 614-615.

(18) Pinhal do Seixo, da Roca, de Montalvo e Benfeita, pinhais nos sítios denominados da Aboboreira, Matos de Fora, Castinhas, Cavadas, Martelo, Cabeço da Malva e Montalvo e havia pinheiros na Gandara da Parada e na Gandara dos Ferreiros.

(19) Sobre a origem e desenvolvimento desta população de pescadores-agricultores, vide: Raquel Soeiro de Brito, Palheiros de Mira, Lisboa, 1960, cap. II. 
mente, o transformaram, criando condições para a sua sobrevivência (20).

O seu número procurámo-lo nos recenseamentos realizados em 1864 , 1878 e 1890 . O recenseamento de 1864 apresenta para Mira 6014 habitantes, o de 1878, 6371 e o de 1890, 7283. Da análise destes números infere-se que a população cresceu ao longo do período, tendência que se regista, aliás, a nível do país.

Este crescimento da população encontra a sua expressão na conquista de novos espaços de cultura que atrás referimos. A relação entre crescimento populacional, intensificação e extensificação da área cultivada também é bem perceptível, neste período, noutras regiões (21).

A população de Mira dedicava-se fundamentalmente à agricultura. Das 7283 pessoas recenseadas em 1890, 5950, isto é, $81 \%$, foram incluídas na rubrica «trabalhos agrícolas». Os recenseamentos anteriores não nos apresentam a composição sócio-profissional, o que nos impossibilita de conhecer as percentagens de população que se dedicava à agricultura e a outras actividades. Quanto à pesca, os elementos que possuímos, ainda que não muito seguros, pois não fizemos investigação profunda, levam-nos a pensar que era uma actividade pouco rentável (22).

(20) «É conhecido o genio activo e trabalhador dos habitantes da Beira e Trás-os-Montes e é proverbial a sua sobriedade. Com tais predicados não admira que transformem em poucos anos as areias movediças das dunas do litoral em produtivas terras e em pinhais de abrigo, indo assim conquistando passo a passo e sem auxílio algum, as areias que tendem constantemente a invadir as terras que com elas confinam» (Gerardo Pery, Geografia e Estatistica Geral de Portugal e Colónias, Lisboa, 1875 , p. 100).

(21) Miriam Halpern Pereira, op. cit., pp. 58-77.

(22) Em 1866 o administrador do concelho de Mira, em resposta a uma circular do Governador Civil sobre pauperismo e mendicidade, afirmava: «O pauperismo n'este concelho é especialmente filho da classe piscatoria e proletaria». Como causas da pobreza apresentava os «matrimonios prematuros» realizados nas idades de 20 a 25 anos e a «mui grande escassez de pescado, trabalho em que se emprega aquella classe de individuos que havera cerca de 15 annos não lucram annualmente, termo medio, doze mil reis cada um». (Arquivo da Universidade de Coimbra (= A.U.C.), Governo Civil (= G.C.), Maço Administradores Municipais, 1857-79).

Em 1875 a Câmara Municipal de Mira escrevia numa representação dirigida ao rei: «Ha neste concelho uma outra industria, a da pesca, que essa ha mais de 10 annos a esta parte longe de dar resultado favoravel aos que nela se empregam tem-lhe sido prejudicial porque não tem tido rendimento que chegue para as despesas, achando-se tais empresas em dívidas fabulosas e quasi perdidas por falta de braços 
Saber que a maioria da população de Mira vivia da terra é importante para o estudo em questão, mas seria importante, também, saber como se estruturavam as relações entre os homens a partir da ligação que tinham com a terra que trabalhavam. Uma elucidação desta questão envolveria pesquisas que não cabem no âmbito deste trabalho. Vamos apresentar, apenas, algumas achegas.

Com o objectivo de conhecer as categorias sociais que teriam uma maior relação com a agricultura, consultámos alguns recenseamentos eleitorais e recenseamentos militares. Neles encontramos as categorias de proprietário, lavrador, seareiro e trabalhador (23). Mas, se o enquadramento destas categorias sociais não envolve grande dificuldade, o mesmo não acontece com a definição do seu significado económico e social e da sua relação com a terra. As categorias de proprietário e trabalhador encontram-se, a priori, em campos opostos relativamente à posse dos meios de produção, mas como enquadrar as categorias de seareiro e lavrador? A dificuldade reside na indefinição e diversidade da terminologia do mundo rural e complica-se, neste caso, devido à constatação da inexistência de uniformidade nos critérios que presidiam à inclusão na categoria de lavrador e seareiro e que se denuncia na variação da sua expressão quantitativa. O quantitativo de contribuição pago pelos seareiros e lavradores também não permite estabelecer uma distinção entre as duas categorias.

$\mathrm{Na}$ documentação que consultámos não encontrámos qualquer elemento que nos permita esclarecer esta questão. A atitude da população de Mira aparece-nos bipolarizada apenas em dois grupos sociais: os proprietários e o povo.

Poderemos, portanto, englobar as categorias de trabalhador, seareiro e lavrador no grupo designado pela palavra povo e entender esta como a designação dada ao conjunto de pessoas que eram assalariados

que das mesmas sucidades (sic) tem saído" (A.M.M., L.A., 1873-78, f. 137v.-138).

A precária situação económica dos pescadores reflecte-se nas listas de Recenseamento político. Em 1865 são recenseados 222 pescadores; em 1875 não é recenseado nenhum; em 1886 são recenseados 46 e em 1895 nenhum. (A.U.C., G.C.: Maço Administradores Municipais, 1857-79).

(23) Outras categorias sociais extraíam parte da sua subsistência do amanho das terras. Raquel Soeiro de Brito, referindo-se aos pescadores do lugar de Palheiros, afirma que os caracterizava uma «dualidade de estilos de vida, a pesca e a agricultura, esta praticada sobretudo pelas mulheres» (Raquel Soeiro de Brito, op. cit., p. 35). 
rurais, rendeiros, ou quiçá, em alguns casos, detentores de pequenas parcelas de terra $\left({ }^{24}\right)$ ? A confirmar-se esta hipótese, a propriedade estava concentrada num pequeno grupo (25).

Embora tendo perfeita consciência da precaridade dos dados apontados relativamente à sociedade de Mira, atrevemo-nos a referi-los pelo menos para dar ideia da limitação que nos advém para a compreensão do tema em estudo, do insuficiente conhecimento do tecido social de Mira, na segunda metade do séc. XIX.

Sendo a agricultura a actividade económica predominante, o nível de vida da população de Mira estava intrinsecamente dependente da produção e produtividade agrícolas. Em 1875, a Câmara, numa representação dirigida ao rei, pedia que fosse construída uma estrada - a estrada de Mira à Figueira, para dar trabalho à população, que, «vivendo quasi exclusivamente da industria agricola», nem sequer tinha assegurada a alimentação para a quarta parte do ano. «Uma estiagem de meses nunca interrompida e o soprar constante de impetuosas ventanias» tinham destruído as «searas» de batata, feijão e milho (26). Condições climatéricas adversas vinham agravar a prática de uma actividade que, em si, já não era favorável. Na mesma representação, afirmava-se que os habitantes de Mira dedicavam à agricultura «um lidar constante e um trabalho que talvez por nenhum exceda» (27). Efectivamente, o homem trabalhava a terra em condições particularmente difíceis, dadas as características do solo e as técnicas agrícolas de que podia dispor. O solo de Mira, com uma constituição geológica arenosa, tinha uma fertilidade natural muito baixa. Dado que o adubo químico e a máquina ainda não estavam vulgarizados, a produção e produtividade agrícolas ficavam, assim, dependentes do esforço humano que se traduzia no amanho da terra e na procura de elementos nutritivos para a fertilizar (28).

(24) Sobre os significados da palavra povo vide: Joel Serrão, Povo, in «Dicionário de História de Portugal», vol. III, Lisboa, 1971, pp. 459-468.

(25) Na lista de recenseamento eleitoral de 1865 constam 25 proprietários, na de 1875, 29, na de 1866, 25 e na de 1895, 19. (A.U.C.: G.C., Maços de Recenseamento Político).

(26) A.M.M.: L.A., 1873-78, f. 113 v.

(27) Idem.

(28) «Foi um trabalho de séculos que transformou estas magras areias. Se há regiões onde se pode falar num enriquecimento do solo por «acumulação de trabalho 
Dadas as características do solo, da fertilização dependia a quantidade e qualidade das colheitas. Sendo o estrume o sustentáculo da agricultura, a sua aquisição constituía a grande preocupação do agricultor (29). Como fertilizantes ele utilizava os limos das lagoas e valas, o moliço ( $\left.{ }^{30}\right)$, os adubos vegetais e o estrume animal. Da documentação consultada infere-se que o estrume vegetal era o utilizado em maior escala.

A criação de gado constituía, também, uma exigência desta agricultura, pois fornecia o precioso fertilizante e ajudava o homem a revolver a terra e a transportar alfaias, estrumes e produtos agrícolas (31).

Assim, da prática de uma agricultura em que os adubos vegetais e animais ainda não tinham sido substituídos pelo adubo químico e em que a alimentação do gado era feita à base de vegetação espontânea decorria uma relação de complementaridade e dependência entre a área cultivada e a inculta. A relação estabelecida pela população entre baldios e sobrevivência da agricultura é deste facto expressão significativa.

Analisámos nas páginas anteriores a relação existente entre os baldios e a actividade agro-pecuária desenvolvida em Mira. Mas a utilização dos baldios de Mira não se restringia à comunidade dos vizinhos. Durante a segunda metade do séc. XIX, gados de fora do concelho vinham periodicamente pastar nestes terrenos.

humano» a Gândara e a Gafanha, que a continua para Norte, estão bem dentro deste caso». (Jorge Gaspar, As feiras de gado na Beira Litoral, Lisboa, 1970, p. 32).

(29) «Usado com moliço e pilado, nos locais onde estes chegam, ou simples, até à generalização dos adubos químicos, o estrume tem sido um dos mais fortes esteios da agricultura da Gândara». (Jorge Gaspar, op. cit., p. 32).

(30) A utilização do moliço na agricultura foi já registada nas Informações Paroquiais de 1758: «Cria esta lagoa muyto lodo e ervas a que chamaõ murrassa ou molisso, de que se utilizaõ os lavradores, tirando o e apanhando o engenhosamente para a cultura das suas terras e com elle semearem as suas novidades» (T. do Tombo: «Diccionario Geographico de Portugal», tomo XXIII, n. ${ }^{0}$ 152, p. 990).

(31) O recenseamento de gado feito em 1870 apresenta para Mira as espécies de gado cavalar, bovino, suíno, muar, caprino e asinino, mas a espécie com maior expressão quantitativa é a cavalar. Mira é o concelho do distrito de Coimbra que tem maior número de cavalos. $\mathrm{O}$ facto é explicado no relatório que acompanha o recenseamento pela utilização de cavalos e éguas de pequena estatura em vez de bois no serviço de transportes, nomeadamente na condução dos estrumes. (Vide Recenseamento Geral dos gados no continente do Reino de Portugal em 1870, Lisboa, 1873, p. 179, p. 197). 
A abolição do direito de compáscuo e as necessidades de extensão e intensificação da área cultivada levaram a uma progressiva redução dos campos de pastagem e a uma necessidade de substituir pelo regime de estábulo o regime de pastagem exclusiva (32). Este fenómeno verifica-se, em 1870, no distrito de Coimbra, principalmente nos campos do Mondego, onde costumava pastar grande quantidade de gado (33). Mas o regime de estabulação não se generalizou de um modo uniforme em todo o distrito e durante muito tempo coexistiram os regimes mistos de estabulação e pastagem e o regime de pastagem exclusiva. Este último era, aliás, preferido por alguns agricultores descrentes do novo regime de criação de gado (34).

Ora, na documentação que explorámos, está bem documentado o afluxo de gado de fora do concelho, essencialmente de gado vacum e cavalar, vinda que a Câmara aprovava, pois constituía uma das suas fontes de receita (35).

A pecuária estava, como vimos, indissoluvelmente ligada à agricultura (36), mas o afluxo do gado de fora do concelho devia integrar-se

(32) Miriam Halpern Pereira, op. cit., p. 115-126.

(33) Recenseamento Geral dos gados no continente, cit., p. 165.

(34) «O velho preconceito da produção pecuária só ser indústria possível e lucrativa nas regiões pascigosas, onde os terrenos incultos, os logradouros communs, os baldios, maninhos e outras pastagens da mesma natureza dispensam o emprego e consumo das forragens cultivadas, ainda é tida como sentença grave por bom numero de nossos agricultores» (Idem, p. 167).

(35) Em Junho de 1853 a Câmara deliberou proceder ao arrolamento do gado vacum e cavalar de fora do concelho que era apascentado nos baldios (L.A., 1852-1856, f. 32v.). Em 1868 decidiu tributar o gado vacum não domesticado do concelho invocando o facto de os habitantes deste trazerem o gado de fora a pastar com o seu, fugindo assim ao pagamento do imposto (L.A., 1866-68, fs. 137 e 137v.). Em Junho de 1890 a Câmara deliberou fechar alguns baldios à pastagem de gado para proteger os pinhais novos, pois era nesse mês que «costumava aparecer nas pastagens deste concelho grande quantidade de gado vacum e algum cavalar» (L.A., 1890, fls. 46v. e 47). A revogação desta deliberação foi pedida nos anos seguintes e em 1883 a Câmara decidiu conceder licenças para a pastagem de gado nalguns baldios, alegando que com essas licenças «só tem a câmara a lucrar» (L.A., 1893, f. 21v.).

Citamos estes factos, pois eles são expressivos do interesse que criadores de gado tinham nos baldios e do interesse económico que essa pastagem revestia para a Câmara.

(36) «Um dos fins da criação de gado é produzir estrumes», afirma Jorge Gaspar, referindo-se à Beira Litoral (As feiras de gado na Beira Litoral, cit., p. 24). 
na criação com objectivos de exploração comercial, facto que é bem perceptível, neste período, na Beira Litoral (37).

Quanto à existência desta actividade orientada para este fim em Mira, não temos dados suficientemente probatórios. Temos, no entanto, notícia da realização de algumas feiras de gado: em 1758 já se efectuava uma (38); em 1874 havia uma anual e duas mensais, em Mira e em Portomar (39); em 1896 realizava-se uma feira anual e outra mensal em Mira e feiras mensais em Portomar e no Seixo (40). No Recenseamento dos gados refere-se que em Mira as éguas de carga são também «femeas de criação» (41). A criação de éguas era uma «indústria» que se exercia «em grande escala» em 1890, segundo um testemunho da época ( ${ }^{42}$ ).

Os dados referidos, ainda que incompletos, permitem-nos entrever a função económica e social dos baldios, função que ultrapassava a de suplemento de subsistência de estratos sociais de fruste nível de vida, para constituir um complemento imprescindível da agricultura local e servia, até, interesses de pessoas alheias ao concelho.

\section{II}

A lei de desamortização de baldios, publicada em 28 de Agosto de 1869, exceptuava da desamortização os terrenos necessários ao logradouro comum dos povos e estabelecia que a designação e demarcação desses terrenos fosse feita pelo governo «com audiência das administrações interessadas» (art. 2. ${ }^{\circ}, \S$ único) (43).

Em 18 de Dezembro de 1872 publicava-se uma portaria com o objectivo expresso de esclarecer dúvidas «sobre o modo de se dar execução ao $\S$ único do art. $2 .^{\circ}$ da lei de 28 de Agosto de 1869» (44). Reafirmando que ao governo competia a designação e demarcação dos terrenos exceptuados da desamortização, acrescentava que as admi-

(37) Ver Jorge Gaspar, op. cit., pp. 45-47.

(38) Idem, p. 44.

(39) A.U.C.: G.C., maço «Baldios, 1862-63, 1873-74 e 1885-1888».

(40) Jorge Gaspar, op. cit., p. 47.

(41) Recenseamento Geral dos gados no continente, cit., p. 182.

(42) A.M.M.: Livro de Correspondência Expedida, 1888, p. 59.

(43) Colleç̧ão Official da Legislação Portugueza, 1869, p. 394.

(44) Idem, 1872, pp. 348-349. 
nistrações interessadas deviam dirigir com a «possível brevidade» representações ao governo a fim de se concluir a designação e demarcação dos terrenos que julgassem compreendidos na excepção referida na lei, diligência que devia preceder a desamortização. Estabelecia ainda que as câmaras e Juntas de paróquia executassem, «com a maior brevidade», as disposições da lei referentes à desamortização, resolvendo com a aprovação do conselho de Distrito as formas de alienação - venda ou aforamento - dos seus baldios.

A Câmara de Mira, em cumprimento do determinado nesta portaria, dirigiu uma representação ao governo requerendo a exclusão da desamortização de todos os baldios do concelho por os considerar «indispensáveis ao logradouro commum dos povos de Mira» e afirmava que a desamortização dos seus baldios compostos por «diferentes pinhais que facultam aos povos de Mira estrumes para a sua agricultura e de outros terrenos ainda não arvorisados, que proporcionam aos vizinhos do concelho pastagens para os seus gados, acarretaria a morte da agricultura em Mira por que os terrenos agricultados naturalmente arenosos só com muitos adubos é que dão alguma produção, e esses adubos vêm na maxima parte dos baldios municipaes» ( ${ }^{45}$ ).

Apesar desta fundamentação que acompanhava o requerimento de isenção da desamortização dos baldios de Mira, o governo não o deferiu e, em 2 de Outubro de 1873, a Câmara recebia uma circular do governador civil transmitindo as disposições da lei de 28 de Agosto de 1869 e as instruções para a sua execução. Em resposta a esta circular reafirmava a estreita ligação que existia entre os baldios e o amanho das fazendas, «as quais pagam uma grande soma de reis para a Fazenda Nacional, contribuição que não podiam satisfazer faltando-lhes aqueles elementos», mas considerava que uma «pequenita porção» «ainda» podia ser dispensada, pois evitaria algumas usurpações $\left({ }^{46}\right)$.

Entretanto, nas actas referentes aos anos de 1874, 1875 e 1876 não encontramos qualquer referência à desamortização e apenas retomamos o fio deste processo em Maio de 1877 ao lermos numa acta da Câmara que algumas pessoas do concelho, em que se destacava o nome de

(45) Extraído de uma cópia da representação que consta na acta da reunião da Câmara Municipal realizada em 19-Janeiro-1873 (A.M.M.: L.A., 1870-1873, fs. 175v.-176).

(46) Eram 2 terrenos baldios com $500 \mathrm{~m}\left(\mathrm{~m}^{2}\right.$ ?) cada um, situados na Gândara dos Carapellos e na Videira (A.M.M.: L.A., 1870-73, f. 237v.-238). 
3 proprietários, requeriam à Câmara que representasse ao governo os inconvenientes da desamortização dos baldios. A Câmara respondia que julgava conveniente tomar "uma resolução definitiva» sobre os baldios do concelho e ia ocupar-se desse assunto de forma a não «defraudar os interesses municipais» ( $\left.{ }^{47}\right)$. Esta acta é reveladora da não aceitação pelo governo das anteriores resoluções da Câmara nesta matéria.

Embora desconhecendo a forma como foi realizado, em Fevereiro de 1877 fora concluído um inventário de baldios do concelho, inventário parcial, já que dele não constavam os baldios usurpados. Ora, a existência de um inventário era um passo fundamental para a prossecução da desamortização e portanto a este facto não deve ser alheia a representação atrás referida.

Mas, se não era executada a lei da desamortização, a Câmara prosseguia na sua actividade normal de administração dos baldios realizando até a sua desamortização ao autorizar algumas alienações através de aforamentos.

Em Dezembro de 1878 aprovava um requerimento assinado pela «maioria» dos moradores do concelho onde se pedia o aforamento dos baldios «incultos», precedido de divisão pelos mesmos moradores. $O$ requerimento foi deferido, pois considerou-se que «a desamortização por meio de aforamento de certos e determinados baldios era imensamente conveniente para o engrandecimento da agricultura e para o município uma verba importante de receita», e decidiu aforar alguns baldios após a repartição e estabelecimento de foros pelos louvados, reservando para «tempo oportuno» a desamortização dos restantes terrenos (48). Resolveu ainda dar conhecimento desta divisão ao conselho de Distrito.

Mas, uma vez que a Câmara não optava pela desamortização total, não podia desamortizar uma parte sem que primeiro fosse demarcada e designada a área de logradouro comum ou optasse por outra modalidade de desamortização para a restante terra baldia $\left({ }^{49}\right)$. E, efec-

(47) A.M.M.: L.A., 1873-1878, f. 246v.

(48) A.M.M.: L.A., 1878-1881, f. 57v.

(49) «...Sempre a designação e demarcação dos terrenos exceptuados se ha de effectuar antes de se realisar a desamortização por qualquer dos meios previstos e declarados na mesma lei» (Portaria do Ministério dos Negócios da Fazenda de 13-Dezembro-1872, in Colleç̧ão Official da Legislação Portugueza, 1872, p. 349). 
tivamente, assim aconteceu. Em 1879 a Câmara deslocava uma verba destinada à divisão dos baldios para as obras de tapamento da Barrinha, uma vez que o processo relativo a este assunto ainda não tinha sido aprovado pela comissão Distrital (50).

Entretanto, ia deferindo ou indeferindo pedidos de aforamento de acordo com o que considerava interesses do município. Em Maio de 1880, decidia aforar um terreno para a instalação de moinhos, emprazamento que, dado o fim a que se destinava, deveria ser feito por «elevado preço», e afirmava ter em vista a divisão dos baldios, com excepção dos pinhais (51).

Se encontramos pedidos de aforamento, encontramos também outros em sentido contrário. Em 1882 «mais de 200 pessoas» apresentaram um requerimento, assinado por 114, para que não fossem aforados alguns baldios. A Câmara aceitou o pedido (52). No mesmo ano deliberava não arrematar algumas glebas de terreno que tinha decidido aforar nos baldios da Barra e Videira, dado que eram imprescindíveis para o logradouro comum (53).

Decorriam já quinze anos após a publicação da lei de desamortização e o governo não a via aplicada no concelho de Mira, não constituindo, aliás, este concelho caso único no Distrito de Coimbra. Mas, apesar disso, não desistiu, e, a partir de 1884, intensificou esforços no sentido da sua aplicação.

O governador civil passou a enviar frequentes circulares às juntas de paróquia e Câmaras municipais com o objectivo de dinamizar o processo, tentando iniciá-lo com a realização de um inventário global dos baldios. Em 18 de Fevereiro de 1884 enviava uma circular ordenando a inventariação de todos estes. Em 14 de Março de 1885 enviava outra circular dando as instruções para a sua prossecução $\left({ }^{54}\right)$.

A Câmara de Mira, como já referimos, possuía um inventário dos seus baldios, mas estava incompleto pois não continha os usurpados. Dado este facto, o presidente da Câmara, enviou um ofício ao gover-

(50) A.M.M.: L.A., 1878-81, f. 100v.

(51) A.M.M.: L.A., 1878-81, fs. 154-154v.

(52) A.M.M.: L.A., 1881-84, f. 113v.

(53) A.M.M.: L.A., 1881-84, fs. 114v.-115.

(54) A.U.C.: G.C., maço «Baldios 1884-1894». 
nador civil perguntando se deveria realizar um inventário de todos os baldios ou apenas daqueles que não foram incluídos (55). Em resposta o governador civil mandou inventariar apenas os possuídos ilegalmente havia menos de 20 anos (56). Mas este presidente não foi reeleito nas eleições realizadas nesse ano e o seu sucessor não mostrou a mesma receptividade em relação ao inventário.

Com efeito, na terceira reunião realizada sob a sua presidência, analisou a situação dos baldios. Começou por afirmar que a «quazi totalidade» estava ocupada e cultivada. Algumas pessoas que os possuíam encontravam-se numa situação legal, pois o processo de aquisição desses terrenos tinha sido regular e obtido a aprovação dos órgãos competentes, mas a situação de outras era ilegal, ou porque o Conselho de Distrito não aprovara os aforamentos feitos pela Câmara ou porque as terras tinham sido usurpadas. Quanto a estas situações ilegais considerava que se deviam regularizar através da realização de contratos de aforamento com os seus possuidores, uma vez que a Câmara não tinha disponibilidades financeiras para tentar uma recuperação através de processos judiciais, aos quais recorreria, no entanto, se os ilegítimos possuidores não reconhecessem a Câmara como «senhoria directa». Em relação aos baldios ainda incultos era de parecer que, para evitar usurpações, se aforassem em hasta pública ou através da modalidade de divisão pelos vizinhos, «como estes por mais de uma vez ande solicitado». Os vereadores concordaram com a proposta do presidente, considerando que da sua concretização adviria grande receita para o município e a «diminuição da saida de braços para países estrangeiros e longínquos» (57).

Nesta reunião foram ainda tratados outros assuntos referentes a arborização e usurpação de baldios (58), mas não foi exarada em acta

(55) A.U.C.: G.C., maço «Baldios 1884-1894» (Baldios 1887).

(56) A.U.C.: G.C., «Administradores», $1 .^{\mathrm{a}}$ Repartição, Livro 7. ${ }^{\circ}$ (6-Junho-1883 a 25 -Novembro de 1886 ), fs. $126 \mathrm{v} .-127$.

(57) A.M.M.: L.A., 1884-87, fs. 153-153v.

(58) Foi analisado e deferido um requerimento apresentado por 25 pessoas do lugar do Seixo solicitando à Câmara que mandasse semear de pinhão os baldios situados entre o pinhal do Fojo e as dunas. Os requerentes prontificaram-se a colaborar na sementeira dando 4 litros de semente e um dia de trabalho. Foi referida também a incúria de alguns guardas rurais que não apresentavam denúncias das ususpações que havia em todos os baldios e deixavam o gado lanígero destruir o pinhal da Videira. (A.M.M.: L.A., 1884-1886, f. 152v.). 
qualquer referência à lei de desamortização e especificamente à realização do inventário.

A Câmara tentava assim fugir à inventariação dos baldios ilegalmente ocupados, - tarefa propiciadora de conflitos, pelos interesses postos em jogo, e, simultaneamente, instrumento de que estava dependente a aplicação da lei de desamortização aos seus baldios, - propondo a sua desamortização.

Salientamos ainda o facto de o município, pela primeira vez, decidir o aforamento de todos os baldios não fazendo qualquer referência aos terrenos necessários ao logradouro comum. Ora, apesar de o presidente afirmar que a «quasi totalidade» estava ocupada e cultivada, consideramos a expressão exagerada, pois, posteriormente, foram arborizados e aforados baldios, tendo ficado ainda alguns em logradouro comum.

Partirá a proposta do presidente do pressuposto de que o baldio, enquanto logradouro comum, perdera a sua função no contexto sócio-económico de Mira, ou será apenas mais uma tentativa de evitar ou adiar uma desamortização que lhe pretendiam impor? Inclinamo-nos para a segunda hipótese.

Mas o governo, num sentido oposto, acumulava esforços para obter a execução da lei no Distrito de Coimbra. Em 7 de Julho de 1887 o presidente da comissão distrital da Junta Geral do distrito de Coimbra enviava um ofício ao governador civil que, pelo seu significativo conteúdo, transcrevemos: "A comissão executiva, apesar de conhecer as diligências empregadas por V. Ex. ${ }^{a}$ para a realização do inventario de baldios, resolveu, pelo conhecimento que tem da administração das camaras municipais, pedir a V. Ex. ${ }^{a}$ as mais instantes e energicas providencias para a levar a cabo, o mais depressa possível, tão importante serviço, de que muito dependem as finanças das corporações administrativas» (59).

A resolução a curto prazo de dificuldades financeiras constituía um dos motivos que levava o governo a empenhar-se na aplicação da lei de desamortização, motivo que esteve, aliás, subjacente a todo o processo levado a cabo no século XIX.

Se a entidade administradora dos baldios já se debatia com dificuldades na tentativa de resolução, ou não resolução, de um problema

(59) A.U.C.: G.C., maço «Baldios 1884-1894». 
que the vinha do exterior, de repente viu-se a braços com outro levantado por um membro da sua comunidade.

Em 11 de Junho de 1887, a Câmara recebia uma exposição assinada por um proprietário, que exercera o cargo de administrador durante o mandato da vereação transacta, denunciando várias usurpações de baldios e culpando o presidente de ser conivente nalgumas delas feitas por familiares seus, membros da câmara e pelo pároco. O denunciante propunha-se pôr «em juizo as acções competentes contra os usurpadores» no caso de a Câmara as não propor no prazo legal (60).

Esta exposição, publicada pela Imprensa da Universidade de Coimbra, foi divulgada pelo jornal $O$ Conimbricense, que, por sua vez, se empenhou na denúncia da situação, chamando a atenção dos órgãos competentes para a resolução do caso $\left({ }^{61}\right)$.

Perante esta grave acusação, o presidente, numa reunião extraordinária da Câmara, não refutou a existência de usurpações, afirmando até: "Como particular posso levantar bem alto a cabeça e apresentar-me como sendo dos poucos que não hão tomado baldios», mas considerava-se disposto a impedir a consolidação dessas situações (62). Não se referiu, no entanto, áos casos em que era acusado de conivência, preocupando-se mais com fazer acusações do mesmo teor ao presidente que o precedera, afirmando até que o denunciante era apenas um mandatário do seu antecessor (63) que alienara e deixara usurpar «mais de metade de todos os baldios do concelho"y (64).

$\mathrm{Na}$ sequência destas acusações, o governador civil mandou fazer uma sindicância à Câmara de Mira. O sindicante confirmou no seu relatório a existência de muitas usurpações que, segundo ele, datavam «de épocas remotas» e «so com excepção de rarissimas pessoas e daquelas que não pagam decima todos os outros habitantes de Mira possuem terrenos que outrora pertenceram ao município», atribuindo-as aos aforamentos feitos com autorização ou sem ela, mas sem medição,

(60) A.U.C.: G.C., maço «Baldios 1884-1894».

(61) O Conimbricense, n. ${ }^{\text {os }} 4152$ e 4153, ano XL, de 11-6-1887 e 14-6-1887.

(62) Idem, n..$^{\circ}$ 4.155, de 21-6-1887.

(63) O presidente referia-se a Barjona de Freitas, membro do partido progressista, acérrimo opositor da desamortização dos baldios. Exercera o cargo de presidente no mandato transacto, quebrando uma linha de continuidade que vinha sendo mantida, e que continuou posteriormente, pela mesma familia.

(64) Esta defesa, ou mais propriamente denúncia, foi objecto de crítica em artigo publicado no Imparcial (O Imparcial de Coimbra, anno v, 16-7-1887). 
e muito especialmente aos alinhamentos concedidos pelas câmaras. Perante o número de ocupações ilegais, o sindicante considerava necessário gastar muito tempo e o concurso de pessoas competentes para. fazer o inventário desses terrenos (65).

Confirmada a existência de usurpações, o governador civil recomendou à Câmara que utilizasse os meios «suasórios e conciliadores» e os «judiciais e coercivos», em caso de ineficácia daqueles, para reaver as terras ocupadas. Aconselhava-a ainda a recorrer a um orçamento suplementar para financiar os processos judiciais e, quando as despesas a fazer com a recuperação excedessem o valor dos terrenos o governador civil sugeria a imposição de um foro. Exprimia ainda o desejo de que a actuação da Câmara compensasse a incúria havida até aí na administração do património municipal (66).

Por sua vez, a Junta Geral do Distrito punha à apreciação do governador civil a seguinte sugestão para «ultimar de vez o problema dos baldios» a inventariação destes por pessoa estranha às dissenções locais, seguida de demarcação da área de logradouro comum e desamortização da restante, preferindo a divisão pelos vizinhos. Quanto aos terrenos usurpados, alvitrava que se evitassem as «demandas dispendiosas e difíceis» e se exigisse dos ilegítimos possuidores o pagamento de um foro; pois assim se regularizava a administração de tais bens e se obtinha um rendimento importante para a Câmara (67).

A Junta Geral escolhia assim o caminho mais fácil para a resolução do problema dos baldios, em geral, e das usurpações, em particular, indo ao encontro da vontade da Câmara. Mas o governador civil não seguiu o seu alvitre. Não se mostrava disposto a transigir com os ocupantes, legitimando a sua situação através de um contrato de aforamento e pressionava a Câmara para que readquirisse, através da via judicial, pelo menos aqueles terrenos em que as despesas a fazer com a recuperação não excedessem o valor deles (68).

A Câmara, por sua vez, argumentava que não dispunha de meios financeiros para reaver os terrenos e insistia em que a melhor solução

(65) A.U.C.: G.C., maço «Baldios 1884-1894».

(66) A.U.C.: G.C., correspondência Governo Civil - Câmaras, 1879-1887, livro n. ${ }^{\circ} 18.903$, fs. 132v.-133.

(67) A.U.C.: G.C., maço «Baldios 1884-1894».

(68) A.U.C.: G.C., Correspondência Governo Civil - Autoridades e Câmaras, livro referente ao período 5-10-87 a 27-5-92, fs. 17-17v, 
era a legalização dessas situações através da celebração de contratos de aforamento com os possuidores de baldios usurpados.

Entretanto, o governador civil, constatando a ineficácia das suas diligências através de ofícios para a realização do inventário, decidiu enviar uma pessoa encarregada de tão espinhosa tarefa (69).

A sua chegada a Mira provocou uma agitação imediata. A desconfiança e por vezes a hostilidade é reacção vulgar no homem do mundo rural colocado perante um agente do poder central que no seu imaginário logo associa a usurpador dos seus bens ou rendimentos, associação que decorre da sua longa experiência de mais dar do que receber. Esta representação do agente do governo foi, neste caso, reforçada através de «proclamações», afixadas nas paredes, «chamando o povo à revolta» contra o encarregado que vinha «roubar» os baldios.

A ameaça de usurpação, que depois foi identificada com a venda, suscitou a animosidade popular contra o encarregado da inventariação, os louvados e os informadores.

Perante este acolhimento e desencorajado porque não conseguia convencer o povo de que o «illudem», a sua primeira reacção foi desistir. Mas acabou por ficar, provavelmente perante a insistência do governador civil, e conseguiu ainda o «socego» convencendo o povo de que o «enganaram». E convenceu-o prometendo-lhe que «não serão afforados, quanto mais vendidos, os baldios que elles querem para logradouro e sem os quaes elles não podem passar». O encarregado da inventariação mostrava compreender a vontade popular relativamente aos baldios. Sugeria que os aforamentos destes fossem feitos através da modalidade de divisão realizada por louvados e não em praça pública. «Diz o povo, e parece-me que diz bem, se os baldios são aforados em praça só os ricos ficarão com elles e os pobres nada tirão». À praça pública podiam concorrer vizinhos e não vizinhos, portanto só tinha acesso ao aforamento quem tivesse poder económico para competir. Apesar das promessas, o sossego foi efémero, pois a acção escla-

(69) A principal fonte para o conhecimento da agitação popular, ocorrida durante a permanência do encarregado da inventariação dos baldios, são algumas cartas enviadas por este ao governador civil que se encontram num maço com a referência «Baldios 1884-1894» no Arquivo da Universidade de Coimbra, no fundo documental originário do Governo Civil. 
recedora e dissuasora da revolta era neutralizada por grupos que alertavam o povo para uma iminente venda dos baldios.

Nas suas primeiras cartas imputava a primazia na difusão dessa ideia e na oposição aos progressistas, grupo que justificava a sua atitude pelas «desconsiderações» recebidas no governo civil e na Comissão Executiva da Junta Geral. Os progressistas eram o grupo a quem o encarregado atribuía maior poder de mobilização popular e que portanto mais temia. Chegou mesmo a sugerir que se escrevesse ao chefe do partido, Pedro Barjona, «para que elle conduza os seus amigos no verdadeiro caminho», pois estava convencido de que o sucesso da sua missão dependia da posição daquele.

Simultaneamente culpava também os proprietários progressistas e regeneradores, usurpadores de terrenos, e receosos que lhos tirassem.

No meio deste ambiente hostil, conseguiu ainda iniciar o seu trabalho demarcando, com a colaboração da Câmara, a área de logradouro comum. O presidente do município encorajara-o a prosseguir, dizendo-lhe «que era uma covardia recuar perante a opposição d'alguns individuos», referindo-se provavelmente aos progressistas, seus adversários políticos.

Mas depressa surgiu outro obstáculo, talvez o maior, à prossecução do seu trabalho. A Câmara recusou a colaboração, alegando recear que os baldios fossem vendidos e que não se queria «comprometer» com o povo. Por seu lado, o encarregado justificava esta mudança de atitude pelo facto de ele querer incluir no inventário os baldios usurpados havia menos de um ano, nomeadamente os anexados pelo secretário da Câmara.

Com a oposição desta surgiu a dos regeneradores.

Perante este alargamento da oposição, considerava impossível a realização do inventário e afirmava até que a sua vida corria «um certo perigo, porque ninguém tenho a meu lado para me proteger».

Ao mesmo tempo, o administrador, em ofício confidencial enviado ao governador civil, comunicava que o povo resolvera fazer um «alevantamento» para expulsar o encarregado da inventariação, mas desistira ao explicar-se-lhe toda a verdade. Acrescentava no entanto: «Não posso ainda afiançar que não soceda grande desordem, porque o povo já ha muito está suspeitado com estas questões de baldios por terem tentado tirar-lhos já por várias vezes e por verem também que as principaes pessoas do partido regenerador teem em seu poder já uma grande 
parte d'aquelles; sendo porem estas duas razoes que teem dado origem ao que já expuz» (70).

A agitação do povo en Agosto de 1888 era assim um despoletar de tensões acumuladas.

Entretanto, apesar das confissões de desânimo e de impossibilidade de cumprir a sua missão, o encarregado do inventário, em Outubro, ainda permanecia em Mira. O facto reflecte a persistência do governo na realização do inventário. Mas o tom das suas cartas não diferia. Confessava-se só no meio de um povo que se apresentava «ameaçador» e sentia-se impossibilitado de fazer o seu trabalho. Atribuía, agora, a oposição ao povo e «principalmente» aos grandes proprietários, a maior parte dos quais usurpadores de terrenos.

Sob o pano de fundo da agitação popular o nosso informador foi destacando alguns grupos. A estes atribuiu, numa primeira fase, uma conotação política - progressistas e regeneradores - e político-económica - proprietários progressistas e regeneradores. Nas duas últimas cartas ele refere como opositores o povo e os proprietários. Tratar-se-á de uma questão de terminologia ou esta reflectirá uma realidade: os proprietários tentariam aproveitar politicamente o descontentamento popular, mas ao consciencializarem-se do perigo da realização do inventário ultrapassaram as clivagens políticas unindo-se solidariamente na defesa dos interesses comuns?

Através de informações particulares, conseguiu ainda elaborar uma lista dos baldios de que a Câmara andava de posse. Exprimia a sua dificuldade na delimitação dos baldios que confrontavam com propriedades particulares, pois os proprietários dessas terras não estavam interessados em fazê-la.

Comparando esta lista dos baldios com o inventário elaborado em 1877 verificamos que não existem diferenças fundamentais. Ambos apresentam o mesmo número - 21, e, à excepção dos primeiros cinco, na mesma ordem. A lista de 1888 tem apenas a mais a confrontação e medição de dois baldios. Este facto leva-nos a pensar que o encarregado utilizou - ou utilizou apenas - o inventário já existente. Registamos, no entanto, um aumento significativo no valor atribuído a essas terras. Na segunda lista ele quase sempre duplica, chegando

(70) A.U.C.: G.C., maço «Baldios 1884-1894». 
mesmo a quintuplicar, facto que denota uma valorização da terra num período de onze anos.

Após a desistência do encarregado da inventariação, a Câmara pediu autorização à Junta Geral do Distrito para aforar, em praça pública, todos os baldios que não fossem necessários ao logradouro comum. Decidiu ainda «convidar» todos os possuidores de terrenos dessa natureza, usurpados havia menos de 30 anos, a apresentarem-se para se organizarem os processos de aforamento dos mesmos (71). Após tantos esforços do governador civil para obter a recuperação, a Câmara não alterara a sua proposta de resolução do problema.

Esta proposta ainda não tinha sido aprovada (72) quando Mira foi surpreendida pela notícia de que tinha sido marcada a venda em hasta pública de alguns baldios e matas municipais. A difusão de tal nova provocou uma grande agitação da população, por ver concretizada a ideia que tinha motivado a sua atitude em relação ao encarregado do inventário no mesmo mês, Agosto, do ano anterior. Perante a situação, a Câmara e o administrador enviaram representações pedindo a imediata suspensão da venda, a fim de evitar um «levantamento». O administrador atribuía a excitação do povo «fanático pelos baldios municipais» ao facto de considerar a venda uma «expoliação» que o governo lhe queria fazer e acusava os inimigos do governo de propagarem «ideias subversivas», fomentando a revolta (73).

Por sua vez, a Câmara reafirmava a função insubstituível dos baldios adentro da actividade agro-pecuária e sugeria ao governo a aprovação da sua anterior proposta relativamente aos mesmos, pois o povo, que os considerava como "propriedade sua», só tolerava que a Câmara os administrasse ou aforasse. E terminava peremptoriamente: «É isto uma garantia de ordem publica, porque os povos d'este concelho, em negócio de baldios só toleram que a camara os afore ou devida. Escuza pessoa alguma d'aqui ou de fora, tentar tratar em Mira

(71) A área de logradouro comum compreendia todas as matas municipais e os baldios denominados Videira do Norte, Videira do Sul, Barra e Ribeira desde a Lagoa até às Castinhas. Cf., A.U.C.: G.C., maço «Baldios 1884-1894»; A.M.M.: L.A., 1888 , fs. $22-22 \mathrm{v}$.

(72) Relatório da Comissão Executiva da Junta Geral do Distrito de Coimbra para ser apresentado na sessão de Abril de 1889, Coimbra, Imprensa da Universidade, p. 31.

(73) A.U.C.: G.C., maço «Baldios 1884-1894». 
de qualquer assunto, respeitante á venda dos baldios e matas porque o povo não th'o tolera - corre-os e enxota-os e só consente que a camara os administre ou afore» (74).

A Câmara dizia directamente ao governo o que a sua atitude relativamente à desamortização já vinha sugerindo há muito tempo: a ela competia a administração dos baldios e não admitia ingerências nesse campo - ideia que estaria, aliás, também presente na população, pois se a forma de administrar os baldios foi algumas vezes contestada, nunca o foi o seu direito de os administrar.

Esta marcação da venda de baldios levanta-nos algumas perplexidades, pois não encontramos fundamento legal para ela na legislação que regulava a sua desamortização. Embora a venda constituísse uma das modalidades de desamortização prescritas na lei de 28 de Agosto de 1869, competia às entidades administradoras dos baldios a escolha da modalidade de alienação. Ora, tanto a Câmara de Mira como o povo sempre manifestaram preferência pelo aforamento.

A venda só poderia ser feita por iniciativa do governo quando as Câmaras municipais ou juntas de paróquia tivessem escolhido a modalidade de aforamento para a desamortização, e, tendo obtido a aprovação do concelho de Distrito, não efectuassem o contrato no prazo de 3 anos (75). Ora, em Agosto de 1889, ainda não tinha sido aprovada a proposta de desamortização, através de aforamento, de alguns baldios formulada pela Câmara em Setembro de 1888 e, portanto, à luz da legislação que conhecemos, o governo não podia tomar a iniciativa da venda.

Tratar-se-ia apenas de um boato? Apesar dos esforços desenvolvidos, não encontrámos qualquer documento do governo que confirme a marcação da venda. Apenas, no ofício do administrador que acompanhou a representação da Câmara, há um apontamento escrito a lápis, do seguinte teor: "Os baldios foram retirados da praça». Anotações com as mesmas características aparecem noutros ofícios constituindo a decisão do governador civil que depois era oficialmente comunicada, mas, como é evidente, não constitui, por si, um testemunho seguro.

Ainda que a marcação da venda não nos apareça totalmente clara,

(74) Idem.

(75) Vide Instruções para a execução da lei de 28 de Agosto de 1869, Art. 51..$^{\circ}$, in Colleção Official da Legislação Portugueza, 1869, p. 596. 
a resposta dada mostra que, em Mira, se rejeitava essa modalidade de alienação, utilizada na desamortização de outros bens.

A venda não se efectuou e as autoridades centrais, perante as circunstâncias, decidiram aprovar as propostas da Câmara anteriormente formuladas $\left({ }^{76}\right)$.

Após uma persistente luta que travou durante quase duas décadas, a Câmara via aprovada a sua proposta de desamortização de baldios e consequentemente a desistência por parte do governo de lhe impor o que ele pretendia (77).

Posteriormente, em Maio de 1892, 73 pessoas compareceram na Câmara para, «amigavelmente e sem questão», concordarem com a imposição de um foro em terrenos que possuíam ilegalmente (78). A aceitação desta situação deu azo a graves críticas do administrador, pessoa que se destacara, em 1887, na denúncia das usurpações.

No final de todo este processo ficava ainda uma extensa área baldia que tem sido arborizada e cultivada ao longo deste século. A Junta de Colonização Interna reconheceu em Mira 12 baldios abrangendo uma área de 1500 hectares e teve indirectamente conhecimento da existência de outro baldio com uma área de 1000 hectares (79). Anteriormente tinham sido submetidos ao regime florestal 7413 hectares de terreno baldio ( ${ }^{80}$ ). A submissão de baldios ao regime florestal suscitou, durante algum tempo, um movimento de oposição da Câmara e da população, movimento que assumiu um cariz muito semelhante ao anteriormente descrito $\left.{ }^{81}\right)$.

(76) Relatório da Comissão Executiva da Junta Geral do Distrito apresentado na sessão de Abril de 1890, Coimbra, Imprensa da Universidade, 1890, p. 25.

(77) A Câmara decidiu aforar em hasta pública 320 glebas de terreno baldio, repartidas pelos baldios denominados Gândara da Parada, 218; Lagoa, 39; Videira do Sul, 19; Arieiro do Casal de São Tomé, 11; Matos da Valeirinha, 20; Ribeiro de São Tomé, 7; Barra, 6. Estas glebas eram estreitas parcelas de terreno, a maioria com 10 metros de largura e oscilando o comprimento entre 70 e 150 metros, tendo uma delas 384 metros. (A.M.M.: Maço das sessões, 1890, fs. 26, 26v. e 33).

(78) Consultámos as listas de recenseamento eleitoral para tentar conhecer a profissão dos usurpadores e obtivemos os seguintes dados: 54 seareiros, 2 proprietários e 1 ferreiro. Os 23 restantes não constavam da lista, 19 dos quais por serem mulheres.

(79) Reconhecimento dos Baldios do Continente, Junta de Colonização Interna, vol. II, Parte I, Colonização Interna, vol. II, Parte I, Lisboa, 1939, pp. 931-933.

(80) Idem, vol. I, p. 119.

(81) Manuel Alberto Rei, op. cit., pp. 28 e segs. 
Numa tentativa de compreensão da atitude da população de Mira perante a desamortização dos baldios, chegamos à conclusão de que nela intervieram uma multiplicidade de razões. Embora conscientes das limitações que temos na compreensão deste problema - limitações que decorrem da documentação explorada e das nossas possibilidades de inteligibilidade dos complexos fenómenos históricos - vamos apresentar algumas achegas.

1 - A lei de desamortização não criou à população de Mira uma situação inédita.

Já em Janeiro de 1862 tinha sido apresentado na Câmara um documento assinado por 119 pessoas que, em representação de todo o povo, pediam fosse impedida a concretização de um plano, que «alguem» tinha concebido, para aforar todos ou parte dos baldios do concelho. Fundamentavam o seu pedido de conservação do usufruto dos seus baldios alegando que, embora desconhecessem a origem desses terrenos, eram «desde tempos immemoriais lugradouros publicos» administrados pelas Câmaras municipais e constituíam a «unica regalia dos povos e principal riqueza do município». Assinavam o documento pessoas de vários estratos sociais e exercendo diversas profissões. Entre eles destacamos o padre, o professor, o cirurgião, o escrivão da Câmara, negociantes, lavradores, seareiros, pescadores, alfaiates, carpinteiros e taberneiros (82).

Este aforamento não chegou a efectivar-se, mas novo perigo, e talvez mais grave, ameaçou os baldios.

Em Março do mesmo ano, a Câmara dirigia uma representação ao rei em que refutava uma denúncia que lhe "constava» ter sido apresentada na Repartição da Fazenda do Distrito e no Tesouro Público relativa à natureza dos terrenos que consideravam baldios. Os denunciantes alegavam que esses terrenos tinham pertencido à Casa das senhoras Rainhas e portanto eram bens nacionais. Ora, a confirmar-se a denúncia, a natureza jurídica desses bens seria a de «maninho» e não a de «baldio» e, portanto, seriam sujeitos ao regime de alienação dos

(82) A.M.M.: L.A., 1858-66, fs. 115v.-116. 
bens nacionais, perdendo a Câmara o direito de os administrar e o povo a sua posse e usufruto.

Perante esta situação, a Câmara alegava que a posse imemorial que ela e o povo tinham destes terrenos justificava a sua natureza de baldios e exprimia o desejo de que o governo constitucional, «essencialmente respeitador da propriedade», respeitasse essa posse, como o haviam feito os governos absolutos, e verificasse «que só a ambição pouco regrada, o desejo justícimo d'adequerir aquelles baldios sacraficando a milhares de pessoas, botando a desgraça todo um concelho, é que podia inspirar a lembrança tam desgraçada d'uma denuncia de semelhante ordem» (83).

O silêncio das actas referentes aos anos que decorrem de 1863 a 1869 revela-nos que o processo de denúncia não prosseguiu nesse período. Mas os denunciantes, um de Tentúgal, outro de Vagos, não desistiram. E, em Abril de 1869, a Câmara reunia extraordinariamente para apreciar um requerimento dos denunciantes. Disposta a defender os seus direitos perante os tribunais, apresentava agora uma minuciosa fundamentação jurídica da natureza baldia dos terrenos em causa e do direito que lhe advinha de administrar não só os baldios «proprios do concelho», aqueles de que a câmara já recebia rendimento, mas também os de «logradouro comum» (84). A sua argumentação baseava-se no facto de não haver conhecimento da reserva de terrenos em Mira para o rei e da sua posterior doação a um senhorio, e no facto de se provar historicamente a sua administração desses terrenos, mesmo antes de 1833, ano em que foram extintos os Tribunais do Conselho da Real Casa e Estado das Rainhas.

A denúncia não foi confirmada e, logicamente, deste processo resultou uma afirmação para a população de Mira dos direitos que tinha em relação aos baldios, mas ela não podia deixar de constituir mais uma ameaça de usurpação a gravar na sua boa memória. Na representação que a câmara dirigiu ao rei em 1862 lembrava que os denunciantes talvez tivessem esquecido o que tinha acontecido, em 1803, ou 1804, ao capitão-mor de Mira, que, ao pretender usurpar terrenos particulares, provocou um motim popular e foi preso.

(83) A.M.M.: L.A., 1858-1866, f. 139.

(84) A.M.M.: L.A., 1869-1870, f. 197v. a 201. 
2 - O processo decorrente da tentativa de aplicação da lei de desamortização aos baldios de Mira polariza-se na inventariação desses terrenos, instrumento fundamental para a execução da lei. Chegaram a ser realizados dois inventários, mas ambos tinham uma lacuna; deles não constavam os terrenos usurpados. Este facto podia levar-nos a atribuir o insucesso das diligências feitas pelo governo para aplicar a lei às ocupações ilegais e aos seus autores. Esta é, aliás, a explicação que decorre das cartas da pessoa encarregada pelo governador civil de elaborar o segundo inventário. Atribui o insucesso da sua missão aos proprietários prevaricadores que engenhosamente propagaram a ideia de que ele ia «roubar» os baldios, suscitando assim a animosidade popular e retirando depois os seus dividendos ao verem consolidada a posse em que estavam de algumas dessas terras.

Efectivamente, a usurpação de baldios era uma prática muito vulgar em Mira no período estudado. Atestam-no as referências constantes na documentação consultada, o relatório da sindicância feita à câmara e até o testemunho de um presidente desta.

A constatação deste fenómeno leva-nos a uma análise da actuação do município, entidade que assumira a administração desses bens e a quem competia a sua salvaguarda da apropriação abusiva.

Ora, a actuação camarária neste período nem sempre se norteou pela imparcialidade exigida a uma entidade a quem competia a administração de uma propriedade comum do povo e que devia agir em função dos interesses de toda a colectividade. Esta prática suscitou críticas aos contemporâneos e motivou até intervenções do governo e do próprio rei.

Mas, se não temos dúvidas acerca da existência de usurpações e da cumplicidade das câmaras nalgumas delas, essencialmente as praticadas por pessoas com quem os seus membros mantinham relações familiares, de classe ou até partidárias, já é difícil apreender a dimensão exacta do fenómeno, bem como da actuação do município. Esta dificuldade provém da carência de documentos comprovativos das ocupações de baldios, das diligências feitas pela câmara para os recuperar, assim como da validade dos seus argumentos de natureza financeira, para não reaver aqueles que exigiam o recurso a processos judiciais. O envolvimento do problema da usurpação e da cumplicidade camarária na luta político-partidária leva-nos também a pensar num certo empolamento que essas situações revestem. 
Além disso, a usurpação, em Mira, não é sinónimo apenas da tradicional tendência dos proprietários para «crescerem as suas testadas» para os baldios, atitude consentida por membros da sua classe que, tendo nas mãos a administração desses bens, davam cobertura a actos ilegais dos seus amigos e quiçá da sua clientela política. A usurpação, em Mira, assume outra dimensão.

Entre os prevaricadores encontramos o proprietário, o grande proprietário, mas também o seareiro, o lavrador, a mulher viúva, que, por uma forma ilegítima, procuram adquirir uma propriedade para agricultar ou para edificar uma barraca ou um curral.

E, embora não nos seja possível individualizar diferenças de actuação da parte da câmara, vários factos nos atestam a sua preocupação de impedir usurpações e reaver os terrenos, essencialmente os ocupados havia menos de um ano, já que essa recuperação não exigia o recurso a processos judiciais e portanto encargos financeiros que o município alegava não poder suportar. A realização de «vistorias» periódicas, a preocupação manifestada na escolha de guardas rurais e zeladores, encarregados de vigiar os baldios e comunicar as transgressões, a referência à «demolição de tomadias» são indicativos de que, se as câmaras de Mira admitiram usurpações, não consentiram ou quiseram consentir todas. Mas, a avaliar pela frequência do fenómeno e até pela sua reincidência, em alguns casos, a actuação da câmara não era efectivamente eficaz. Além disso, ao longo do período surgiram formas camufladas de usurpação. A concessão de alinhamento, prática que se verifica sobretudo a partir do terceiro quartel do séc. XIX, veio a revelar-se uma forma de obter legalmente autorização para anexações abusivas, já que as pessoas que recebiam autorização para alinhar nem sempre se limitavam ao quantitativo que thes tinha sido concedido e que normalmente pagavam.

Esta impossibilidade prática de reaver baldios ocupados expressa-a a própria Câmara quando justifica a realização de alguns aforamentos como meio de impedir tais anexações.

A composição social dos usurpadores, assim como a atitude, ou atitudes, da Câmara em relação aos seus actos leva-nos a pensar que a oposição à desamortização não pode ser compreendida apenas na perspectiva dos interesses dos ocupantes, mas tem que ter em conta a função económica, social e até política dos baldios, função que, em graus diversos, diz respeito a toda a colectividade e que talvez tenha constituído o elo de união. 
Na representação enviada ao rei, em 1890, a Câmara, colocada perante uma situação que já receava havia muito tempo, a venda dos baldios, reafirma essa função. "Porque os baldios e matas municipais são absolutamente necessários para estes povos pois que é delles que se extrahem os adubos ou estrumes para a cultura das propriedades e estas nada produzem sem estrumes por serem arenosas d'uma aridez extraordinaria e safaras e é nos baldios que apascenta os seus gados. A agricultura do concelho definha completamente sem os baldios e matas» (85). Esta representação não nos traz nada de novo quanto à função dos bens em causa, já que ela está expressa na documentação de todo o período, mas citamo-la porque denota a permanência da função tradicional do baldio - e nomeadamente a complementaridade das áreas inculta e cultivada - nos finais do séc. XIX, a denunciar a inexistência de alterações estruturais nas formas de exploração da terra.

Esta ideia não é apenas um bom argumento para impedir a desamortização dos baldios, pois a Câmara, apesar de ter realizado algumas alienações destas terras, sempre mostrou a necessidade de preservar a área de logradouro comum.

E, posteriormente, em 20 de Março de 1896, num artigo publicado na Gazeta da Figueira, ao analisarem-se as consequências de uma falada divisão dos baldios, acentuava-se que ela era prejudicial à agricultura e desvantajosa para o arrendatário e pequeno proprietário, que, se adquiria uma propriedade, ficava sem estrumes para a adubar, tendo de os pagar proporcionalmente por um preço superior à renda que pagaria pelo cultivo de uma propriedade e concluía-se: «O desiquilíbrio agrícola, entre nós, não é em propriedades, mas sim em estrumes» (86).

Esta função dos baldios justifica por si só a oposição de uma população, que vivia essencialmente da agricultura, à aplicação de uma lei que se lhe representava como potencial usurpadora daquelas terras. Mas a ingerência nos baldios de elementos alheios à Câmara punha em jogo outros interesses, direitos e quiçá esperanças.

Vamos tentar entrevê-los na perspectiva dos não proprietários e pequenos proprietários, dos proprietários e da Câmara.

(85) A.U.C.: G.C., maço «Baldios 1884-1894».

(86) Gazeta da Figueira, ano $5 .^{\circ}, \mathrm{n} .^{\circ} 436$. 
Do que já foi dito facilmente se infere que a sobrevivência dos estratos com débil poder económico estava largamente dependente da fruição dos baldios. Mas o habitante de Mira não pretenderia apenas preservá-los enquanto logradouro comum; concentrava neles, segundo pensamos, a esperança de adquirir uma propriedade ou aumentar a que já possuía.

Numa das cartas que o encarregado de elaborar o inventário dos baldios enviou ao governador civil escrevia que conseguira acalmar os ânimos agitados do povo prometendo-lhe que não seriam aforados, «quanto mais vendidos», os baldios que queriam para logradouro comum e «sem os quaes elles não podem passar», mas afirmava que alguns podiam ser aforados, embora através da modalidade de divisão, «a fim de serem contemplados sómente os povos vizinhos», e acrescentava: «Diz o povo e parece-me que diz bem, se os baldios são aforados em praça só os ricos ficaraõ com elles e os pobres nada tirão».

Também a Câmara manifestou algumas vezes a intenção de proceder à divisão de baldios, satisfazendo assim o que dizia ser vontade do povo. Não temos, no entanto, qualquer referência à alienação que não revestisse a modalidade de aforamento em praça.

$\mathrm{Na}$ vontade do povo de dividir alguns baldios, bem como nalguns pedidos de alinhamento e aforamento e vários casos de usurpação, podemos entrever uma procura de terras que alimentassem e dessem trabalho a uma população crescente.

Lembramos que a Câmara apresentara como justificação do aforamento de baldios a diminuição da emigração.

O baldio desempenhava uma importante função para o povo, que o defendeu ainda com mais força, pois mantinha vivo o sentimento de propriedade desses bens. "O povo não tolera que lhe vendam os baldios e matas, considera-os como propriedade sua», assim escrevia a Câmara na representação enviada ao rei em 1890 (87).

A intervenção do governo nos baldios foi acompanhada de outras intervenções que se inseriam numa tentativa de conhecimento de alguns aspectos da vida económica e social do país, mas que suscitavam da parte do povo as maiores reservas, pois não acreditava que daí lhe adviessem benefícios.

Uma destas intervenções, que tinha como objectivo a realização de um inquérito agrícola, suscitou uma grande agitação do povo, que,

(87) A.U.C.: G.C., Maço «Baldios 1884-1894». 
em algumas localidades, estava já oprimido por um enorme peso tributário. O jornal $O$ Conimbricense noticiava em Janeiro de 1888 tumultos populares em vários pontos do país (88). Em Cantanhede registaram-se motins provocados pela tentativa de execução de uma postura camarária que estabelecia novos impostos sobre a farinha de trigo e de milho, o peixe seco e salgado, à excep̧̧ão da sardinha e do chicharro miúdo, o arroz descascado e o azeite (89). Estes tumultos apresentaram particular violência em Febres e Murtede. Nesta última terra foi assassinado o arrematante dos impostos municipais; na primeira, do confronto entre forças militares e a população resultaram algumas vítimas. A agitação em Febres foi provocada pela imposição fiscal e pelo inquérito agrícola (90).

Nos livros de correspondência do governador civil para os administradores encontramos referências a tumultos populares ocorridos em Mira em Janeiro de 1888 (91). Estes motins motivaram a presença das forças da ordem e foram despoletados, segundo pensamos, pois o governador civil não apresenta no seu ofício a causa dos tumultos, para além de outros factores, pela realização do inquérito agrícola. Levantamos esta hipótese porque o administrador de Mira, em ofício enviado em Maio do mesmo ano, comunicava ao governador civil que estava concluído o referido inquérito no concelho, mas que, no lugar da Presa, o povo obrigara o agente inquiridor a apresentar os boletins, que foram queimados, não o sendo nos restantes lugares devido à presença das forças da ordem (92). A queima de boletins de inquérito registou-se por todo o país.

Os tumultos ocorridos em Mira e em Cantanhede tiveram naturalmente uma ligação, dado que são concelhos limítrofes. O governador civil enviava até instruções do mesmo teor aos administradores dos dois concelhos. Aconselhava-os a estarem de «inteligência» e dava instruções no sentido de as forças militares actuarem com moderação e prudência, intervindo apenas em conflitos graves «e não para abafar simples tumultos e n'estas circunstancias mesmo so depois de esgo-

(88) O Conimbricense, ano XLI, n.os 4.213, 4.215 e 4.217 , de 10,17 e 24 de Janeiro de 1888.

(89) Idem, n. ${ }^{\circ} 4.213$.

(90) Ibidem.

(91) A.U.C.: G.C., Administradores, 1. ${ }^{a}$ Repartição (3-10-87 a 24-7-90), f. 27v.

(92) A.M.M.: Correspondência Expedida, 1888, f. 20v.-21. 
tados todos os meios suasórios» (93). As instruções nem sempre foram cumpridas, o que pode ter levado à demissão do administrador de Mira (94).

Em 16 de Janeiro de 1889, o governador civil, também em ofício enviado ao administrador, referia-se a «alguma tendência para a agitação do povo» (95). No dia anterior, $O$ Conimbricense noticiava que 14 contribuintes tinham impedido de votar os contribuintes da oposição, ganhando fraudulentamente as eleições, pois estavam em minoria (9๑). A tendência para a agitação referida pelo administrador pode estar relacionada com este conflito político-partidário.

É toda esta teia complexa de dados que temos de ter em conta ao tentar compreender a atitude popular.

Os proprietários estiveram sempre presentes nos momentos em que consideravam ameaçada a posse e fruição dos baldios. A complementaridade existente entre a exploração agrícola e o inculto, como fonte de estrumes, será uma das causas, e talvez a de mais forte peso, da sua atitude. Mas o baldio era também campo de pastagem. Ora até que ponto a actividade pecuária tinha já uma orientação comercial e não apenas estritamente agrícola? Esta uma pergunta que já tínhamos formulado e que deixamos em aberto dado que não temos elementos suficientes para the responder. Neste contexto ousamos perguntar: Quais terão sido os interesses que levaram um habitante de Tentúgal e outro de Vagos a fazer uma denúncia da natureza dos baldios em 1862 e 1869? Não seriam criadores de gado interessados na aquisição desses terrenos para os utilizarem como campos de pastagens?

E, para além das motivações referidas, não poderemos deixar de pensar nas eventuais consequências que a nível de salários e estabilidade social traria a desamortização de terrenos donde os trabalhadores das suas terras podiam retirar um complemento para a sua subsistência. Não significaria a desamortização em Mira a proletarização para alguns estratos sociais? Ora, esta situação não conviria aos detentores da terra.

Mas o centro polarizador da resistência à desamortização foi a Câmara Municipal. Esta sua posição enquadra-se na função que the

(93) A.U.C.: G.C., Administradores, 1. ${ }^{\mathrm{a}}$ Repartição (3-10-87 a 24-7-90), f. 27v.

(94) A.U.C.: G.C., Admin.es (3-10-87 a 24-7-90), f. 27v.

(95) A.U.C.: G.C., Admin.es (3-10-87 a 24-7-90), fs. 105v.-106.

(96) $O$ Conimbricense, XIII ano, n. ${ }^{\circ} 4.318$. 
competia, e reivindicava, de administrar os baldios, função que era, aliás, aceite pela população, pois se algumas vezes foi contestada a forma como a Câmara a exercia, nunca foi posto em causa o seu direito de gerir esses bens.

No desempenho desta função, a Câmara regulamentou a fruição dos baldios de logradouro comum, zelou pela sua conservação, aforou, ou pretendeu aforar, aqueles que considerava dispensáveis e arborizou alguns deles.

Na sua atitude de resistência à desamortização, umas vezes expressa de forma ambígua, outras frontal, poderemos entrever interesses vários. Os interesses do grupo social donde provinham os seus membros, que já esboçámos em páginas anteriores, e, em determinados momentos, os interesses da corrente política que representavam.

Mas não eram apenas os interesses de um grupo que estavam em causa, eram os de um concelho que a Câmara, como órgão administrativo, devia defender e promover.

Mira era um dos concelhos mais pequenos em área e população do distrito de Coimbra e com precários recursos (97). Consultando os orçamentos da Câmara, não a sua totalidade pois apenas vimos, para este efeito, os livros das actas (e nem todos constam destes livros), verificámos que as fontes de receita do município eram diminutas. Neles se encontram as seguintes rubricas: foros de baldios, renda das «ervagens», assentos das lojas nos mercados e feiras, multas, taxas pela aferição de pesos e medidas, impostos sobre géneros de consumo (sal, vinho e aguardente) e a contribuição directa de repartição (contribuição predial, industrial e pessoal).

Neste contexto os baldios eram uma importante fonte de receita. A receita provinha do arrendamente das ervagens, das multas pagas pelos transgressores dos regulamentos de uso dos baldios, dos foros pagos pelos particulares que tinham adquirido terrenos desta natureza, que a Câmara denominava como «próprios do concelho», e das madeiras extraídas dos arborizados. E poderemos dizer, até, que eram uma

(97) No relatório apresentado à Junta Geral do Distrito pela Comissão Distrital em 1874, podemos encontrar uma série de informações relativas ao distrito de Coimbra que vão desde a área e constituição geológica do solo aos recursos e potencialidades económicas. Vide Relatório apresentado à Junta Geral do Distrito pela Comissão Distrital em 1874, cit. 
reserva potencial de receita, pois a eles podia recorrer em caso de aperto financeiro. Em 1875 aforavam-se 57 parcelas de terreno na Videira para prover às despesas da construção e reparação de estradas e em 1890 a Câmara afirmava que para a construção da estrada da Lagoa à Praia canalizaria parte do produto dos aforamentos que ia fazer.

Em alguns períodos a Câmara chegou mesmo a tributar os gados do concelho que pastavam nos baldios.

Além disso, se tivermos em conta a estreita relação existente entre a agricultura, principal actividade económica em Mira, e os baldios, teremos de considerar que era necessário o contributo destes, para a criação da restante matéria colectável.

As dificuldades financeiras do município podem ter condicionado até a forma como a Câmara administrava os baldios e procedia à sua alienação. $\mathrm{O}$ aforamento em hasta pública, modalidade a que podiam ter acesso vizinhos e não vizinhos, geradora de concorrência e portanto susceptível de obter foros mais altos, a sua preferência pelo arbitramento de foros aos terrenos usurpados e a não adopção da modalidade de venda, balão de oxigénio que satisfaria necessidades económicas imediatas, mas extinguiria uma fonte contínua de receita, podem justificar-se, ainda que não na sua totalidade, por factores dessa natureza.

Nesta linha de pensamento, a sobrevivência económica do concelho estava muito dependente dos baldios e de a sua administração ser feita pela Câmara. E não podemos esquecer que a sua independência não era estável, pois reformas administrativas ocorridas na segunda metade do século XIX fizeram a sua integração, ainda que temporária, no concelho de Cantanhede.

Mas, para além de interesses de ordem económica que a aplicação da lei punha em jogo, ela significava para a Câmara um cerceamento dos seus direitos e do seu poder. A não aceitação das propostas iniciais de isenção de desamortização e as várias tentativas de aplicar a lei não podiam deixar de significar uma ingerência abusiva em áreas que a Câmara considerava da sua competência. A forma como esta termina a representação que endereça em 1889 ao rei é bem expressiva da rejeição de uma intromissão que considerava indevida: «Escuza pessoa alguma d'aqui ou de fora, tentar tratar em Mira de qualquer assumpto, respeitante a venda dos baldios e matas porque o povo não lh'o tolera - corre-os e enxota-os e so consente que a camara os administre ou afore». 
3-Vimos que a tentativa de aplicação da lei de desamortização desencadeou em Mira um complexo processo em que se entrecruzaram interesses económicos, sociais e políticos provenientes de indivíduos, de grupos e da colectividade. No decorrer deste processo pressentimos tensões e clivagens, mas nos momentos cruciais a população agiu como um todo harmonioso. Esta solidariedade alicerçou-se, segundo pensamos, no facto de se considerar em causa a fruição de uma forma de propriedade que ainda não perdera a sua função essencial e constituía um factor de equilíbrio económico e social.

Mas, durante duas décadas, a população reagiu contra a aplicação de uma lei que expressamente salvaguardava a função tradicional dos baldios ao isentar a área de logradouro comum.

É que ela desconfiava da aplicação da lei e talvez com razão. Nem sempre na mente dos seus executores está presente a diversidade de níveis de desenvolvimento e de ritmos de crescimento. Se no séc. XIX, e até no séc. XVIII, em algumas regiões, os baldios tinham perdido a sua função e constituíam áreas cujo aproveitamento agrícola, ou florestal, era mais proveitoso para os seus usufruidores, no séc. $\mathrm{XX}$, em Mira, ainda havia baldios que preservavam a sua função. As pessoas encarregadas pela Junta de Colonização Interna de fazerem o reconhecimento dos de Mira escrevem: «Se incultos ainda existem, não é porque o povo não precise dos terrenos para a cultura, mas porque a falta de matos e o elevado preço do moliço afastam as possibilidades de a fazer» (98).

Maria Margarida Sobral Neto

(98) Reconhecimento dos Baldios do Continente, cit., vol. I, anexo n. ${ }^{\circ}$ 2, p. 66. 


\section{APÊNDICE DOCUMENTAL}

Carta do encarregado do inventário para o Secretário Geral do Distrito de Coimbra (16 de Agosto de 1888)

Ill. mo e Ex. ${ }^{\text {mo }}$ Snr.

Cumpre-me partecipar a V. Ex. ${ }^{a}$ que se ameaça alterar a ordem publica n'este concelho, e teem sido affixadas proclamações nas paredes das casas chamando o povo á revolta contra mim, que venho aqui para roubar os baldios. Todos os meios tenho empregado para convencer o povo de que o illudem, mas nada posso conseguir deste povo ignorante e mau. E não é só contra mim que se dirigem as ameaças, é também contra as pessoas indicadas para louvados e informadores.

É pois impossível cumprir a minha missão. Não retiro já para Coimbra, porque espero as ordens do Exm. ${ }^{\circ} \mathrm{Snr}$. Governador civil, a quem V. Ex. ${ }^{a}$ se dignara dar conhecimento desta minha carta, e mesmo porque receio soffrer algum desgosto na passagem por Mira, visto que os animos se acham muito exaltados. Sou com a maior consideração e estima de V. Ex. ${ }^{a}$.

Mira 16 de Agosto de 1888

Eduardo da Silva Vieira

(A.U.C.: G.C., maço «Baldios 1884-1894», 14-6)

2

Carta do encarregado do inventário para o Secretário Geral do Distrito de Coimbra (20 de Agosto de 1888)

Ill. ${ }^{\text {mo }}$ e Ex. ${ }^{\text {mo }}$ Snr.

Ha socego em todo o concelho de Mira. O povo vai-se convencendo de que o enganaram dizendo-lhe que eu vinha vender os baldios. E o que é para extranhar é partir a opposição dos que se dizem progressistas. Pretendem elles justificar o seu procedimento com as desconsiderações que dizem ter recebido no governo civil e na Commissão Executiva da Junta Geral do Distrito. O que digo a V. Ex. a é que emprego todos os meios para que a ordem não seja alterada, e esforço-me por ser prudente, imparcial e justo. Do que for occorrendo darei parte a V. Ex. ${ }^{a}$.

Sou com toda a consideração e estima

Mira 20-Agosto-1888

Eduardo da Silva Vieira

(A.U.C.: G.C., maço «Baldios 1884-1894», 14-6) 


\section{Carta do encarregado do inventário para o Governador Civil \\ (21 de Agosto de 1888) \\ Ill. ${ }^{\text {mo }}$ e Ex. ${ }^{\text {mo }}$ Senhor}

Cumpre-me partecipar a V. Ex. ${ }^{a}$ que teem apparecido grandes difficuldades á feitura do inventário dos baldios deste concelho. Alguns progressistas, que dizem não terem sido attendidos nas suas pretensões, e alguns proprietarios, progressistas e regeneradores, que teem usurpado terrenos pertencentes ao municipio, e que receiam que lh'os tirem, teem propalado por todo o concelho que eu vim a mandado do governo para vender os baldios, e teem aconselhado o povo á revolta. E o povo mostrou-se excitado ameaçando-me a mim e aos individuos indicados para louvados e informadores. Hoje porém está o povo convencido de que era illudido e ouve-me com attenção por que lhe faço ver toda a verdade e lhe tenho promettido que não serão aforados, quanto mais vendidos, os baldios que elles querem para logradouro e sem os quaes elles, não podem passar. E já consegui que a camara delibere reservar para logradouro do povo esses mesmos baldios. Para esse fim reune ella na quinta feira proxima. Vai tambem a camara deliberar nesse mesmo dia o aforamento d'uns certos baldios. Não julgo conveniente que esse aforamento seja feito em praça e parece-me preferivel o aforamento por meio da divisão feita por louvados, a fim de serem contemplados sómente os povos vizinhos. A não se fazer isto teremos novas difficuldades. Diz o povo e parece-me que diz bem, se os baldios são aforados em praça só os ricos ficarão com elles e os pobres nada tirão. É bastante espinhosa esta minha missão, e para que a possa cumprir sem alteração da ordem é mister encaminhar as cousas de maneira a não provocar desaggrados no povo, e que elle não seja prejudicado. Estou intimamente convencido que, se o partido progressista d'aqui me não hostilizar no desempenho da minha missão tudo correrá na melhor ordem. E para que essa hostilidade não continue julgo conveniente, e até indispensável, que alguem escreva ao Pedro Barjona, chefe do partido progressista de Mira, para que elle conduza os seus amigos ao verdadeiro caminho. Eu ja lhe fallei e respondeu-me elle que não queria indispor-se com o povo. Já V. Ex. ${ }^{\text {a }}$ vê como elle recebe o serviço que venho fazer.

Do que for occorrendo darei parte a V. Ex. ${ }^{a}$.

Deus Guarde a V. Ex. ${ }^{a}$

111. ${ }^{\text {mo }}$ e Ex. ${ }^{\text {mo }}$ Senhor Conselheiro Governador civil do distrito de Coimbra.

Coimbra 21 d'Agosto de 1888

Eduardo da Silva Vieira

(A.U.C.: G.C., «Baldios 1884-1894», 14-4) 
4

\author{
Carta do encarregado do inventário para o Governador Civil \\ (28 de Agosto de 1888) \\ Ill. mo e Ex. ${ }^{\text {mo }}$ Snr.
}

Cumpre-me partecipar a V. Ex. ${ }^{2}$ que a opposição á feitura do inventario dos baldios deste concelho não parte agora somente dos que se dizem progressistas, e sim tambem da propria camara municipal, que á ultima hora se declarou contra o serviço que ella mostrava querer para interesse seu e do municipio.

Tinha eu combinado com o presidente da camara reunir esta em sessão extraordinaria, a fim de deliberar quais os baldios que haviam de ficar para logradouro commum, e depois d'elle me indicar esses baldios, promettendo-me entregar a copia da acta da sessão para a remeter para Coimbra, a fim de ser approvada, declara que a camara não quer comprometer-se com o povo, que nenhum dos seus amigos politicos queria ser louvado, que o povo estava bastante excitado, que, em summa, não se podia fazer o inventario, e que receiava que o governo mandasse vender os baldios, como já em tempo, segundo lhe dissera o Poiares, de Cantanhede, os quizera vender. Este procedimento da camara, depois do seu presidente me ter dito que era uma covardia recuar perante a opposição d'alguns individuos, não se justifica a meu ver. Tem porem a seguinte explicação:

Tendo-me dito o administrador do concelho que o secretario da camara ainda ha menos d'um mez se apossou de terrenos baldios, para lhe serem aforados particularmente, e que esta usurpação era muito censurada, fallei a este respeito com o presidente da camara e disse-lhe que todos os baldios usurpados ha menos d'anno deviam entrar no inventario, e só deviam ser aforados nos termos da lei. Foi então que a camara se declarou em opposição ao inventario, e por conselho de secretario, que muito formalmente me declarou que a camara não queria saber de nada com respeito ao inventario, e que este se não podia fazer. Foi sem duvida o receio que elle tem de ficar sem os terrenos usurpados, que occasionou este ultimo procedimento da camara.

Nestas circunstancias, havendo opposição por parte dos regeneradores e progressistas, que fazem convencer o povo de que eu venho a mandado do governo para vender os bäldios, é absolutamente impossivel fazer-se o inventario nos termos da leì. $O$ que posso conseguir, por informações particulares, é somente a descripção e confrontações dos baldios, sem me fazer acompanhar de louvados. Tenho luctado constantemente com difficuldades e vejo que a minha vida corre um certo perigo, porque ninguem tenho a meu lado para me proteger.

Aguardo as ordens de V. E. ${ }^{a}$ para as cumprir, e rogo a V. E. ${ }^{a}$ se digne dizer-me o que hei de fazer.

Aproveito a occasião para dizer a V. E. ${ }^{a}$ que o Exm. ${ }^{\circ}$ Inspector de Fazenda me officiou partecipando-me que a minha gratificação é apenas de $50 \$ 000$ reis mensais e não de 4500 reis diarios como V. E. ${ }^{a}$ contractou comigo, e isto por virtude do officio da Direç̧ão Geral dos Proprios Nacionais de 21 de Setembro de 1887. Fiquei realmente surprehendido com uma tal partecipação, pois que eu fui nomeado nos 
mesmos termos em que havia sido o fallecido Simão Maria d'Almeida e este, segundo o officio da mesma Direcção, de 14 de Novembro de 1888, tinha direito a receber a gratificação de $90 \$ 000$ reis mensais ou uma libra por dia. E parece que este segundo officio é que deve vigorar e não o primeiro. Rogo, pois, a V. E. . se digne fazer valer o nosso contracto, perfeitamente em harmonia com aquelle segundo officio. Por $50 \$ 000$ reis mensais não deixaria eu o meu escriptorio, para vir desempenhar uma missão que pode trazer-me muitos desgostos, e alguns já tenho soffrido, e que pode traser-me a morte. Confio em que V. E. ${ }^{a}$ me fará justiça devida não consentindo que eu seja prejudicado.

Deus guarde a V. Ex. ${ }^{\mathrm{a}}$.

Mira 28 de Agosto de 1888

Il. ${ }^{\text {mo }}$ e Ex. ${ }^{\text {mo }}$ Snr. Conselheiro Governador Civil de Coimbra Eduardo da Silva Vieira

[À margem, :] «Sobre o terreno usurpado pelo secret. da camara off. ad. ${ }^{\text {or }}$ de Setembro de 1888 .

Na mesma data se oficiou á camara exigindo por cópia acta da sessão em que deliberou sobre a forma de desamortização dos terrenos baldios.

(A.U.C.: G.C., «Baldios 1884-1894», 14-21)

5

Oficio do encarregado do inventário para o Governador Civil (8 de Outubro de 1888)

$$
\text { III. mo e Ex. }{ }^{\text {mo }} \mathrm{Snr} \text {. }
$$

Não tendo podido fazer o inventario dos baldios do concelho de Mira nos termos da lei, pela grande opposição do povo, e principalmente dos grandes proprietarios, a maior parte dos quaes tem usurpado terrenos pertencentes ao municipio, e ainda porque não encontrei auxilio algum da parte do administrador do concelho e da propria camara, vendo-me eu completamente só no meio d'um povo que se apresentava ameaçador, muito particularmente poude colher os dados precisos para organizar o trabalho que envio a V. Ex. ${ }^{a}$, o unico que foi possivel fazer-se.

Ja em Agosto eu officiei a V. Ex. ${ }^{a}$ dizendo que, em vista das hostilidades do povo e do nenhum auxilio da auctoridade administrativa, se tornou impossivel a inventariação dos baldios, e que somente podia fazer o serviço nos termos que acabo de expor a V. Ex. ${ }^{a}$.

Cumpre-me informar a V. Ex. ${ }^{\mathrm{a}}$ que estão aforados terrenos baldios, mas não se acham approvados os afforamentos. $E$ tambem teem sido usurpados terrenos nos sitios de S. Tomé, da Ermida e da Lagôa, com conhecimento da camara, e mesmo 
com approvação sua. E este estado de cousas continuará se o governo não tomar providências energicas.

Deus guarde a V. Ex.a.

II. ${ }^{\text {mo }}$ e Ex. ${ }^{\text {mo }}$ Snr. Conselheiro Governador Civil de Coimbra.

Coimbra 8 de Outubro de 1888

O encarregado da inventariação dos baldios

Eduardo da Silva Vieira

[À margem, escrito a lápis:] «Não declara os nomes dos intrusos possuidores = foi devolvido para que se declarem»».

(A.U.C.: G.C., maço «Baldios 1884-1894», 14-21)

Relação dos baldios do concelho de Mira

1. Um pousio denominado a "Videira do Norte» que confronta do Nascente e Poente com areal, Norte com o prazo da barra e areal, e Sul com a valla d'agua que vai da Lagôa para a Barrinha.

Este terreno mede, pelo menos oitocentos ares ou oitenta mil metros quadrados, e vale seguramente $-24.000 \$ 000 \mathrm{rs}$, calculando-se a $30 \$ 000 \mathrm{rs}$. cada are ou 100 metros quadrados.

2. Um pousio na Videira do Sul, que confronta do Nascente, Poente e Sul com areal, e Norte com a valla d'agua acima referida. Mede uns 200 ares ou vinte mil metros quadrados e vale $6.000 \$ 000$ rs.

3. Um terreno denominado «Gandara do Porto-mar», que confronta do Nascente com Luis Antonio d'Oliveira e outros; Poente com herdeiros de Joaquim da Costa Pimentel de Mira; Norte com areal e Sul com caminho publico. Vale $2.000 \$ 000$ rs.; 4. ${ }^{\circ}$ Um pinhal denominado o "Pinhal do Seixo» que confronta do Nascente com a Gandara da Parada, Poente com areal; Norte com baldio do concelho de Vagos, e Sul com o logar do Seixo. Vale $1.000 \$ 000$ rs.

5. Um pousio com alguns pinheiros denominado a «Gandara da Parada» que confronta do Nascente com caminho publico, Poente com o pinhal do Seixo; Norte com baldio do concelho de Vagos e Sul com o logar de Carapelhos. Vale 6.000\$000 rs. 6. Um pousio com alguns pinheiros denominado "Gandara dos Ferreiros» que confronta do Nascente com varios, Poente com valla real e Sul con Joaquim Moreira, Vale $1.000 \$ 000 \mathrm{rs}$.

7..$^{\circ}$ Um pinhal denominado o «Pinhal da Rossa» que confronta do Nascente com herdeiros de Jacinto Mendes; Poente com caminho publico; Norte com José Callixto e Sul com caminho publico. Vale $100 \$ 000$ rs.

8. ${ }^{\circ}$ Um pinhal no sitio da Aboreira (sic), que confronta do Nascente com Manuel Domingos Louro e outros; Poente com Custodio Damazio; Norte com o rio e Sul com Antonio d'Oliveira. Vale $1.000 \$ 000$ rs.

9. Um pinhal e pousio nos Mattos de Fora que confronta do Nascente com João do Fresco; Poente com Manuel Clemente, Norte com João Domingos Louro, e Sul com Luiz Moreira, vale $400 \$ 000$ rs. 
10. Um pinhal no sítio das Castinhas que confronta do Nascente com Manuel Maria Callixto, Norte com valla dos Moinhos e Sul com baldio do concelho de Cantanhede. Vale $15.000 \$ 000$ rs.

11. Um pousio no mesmo sitio das Castinhas que confronta do Nascente e Norte com a valla dos Moinhos, Poente com areal e Sul com terreno baldio. Vale $500 \$ 000$ rs. 12. ${ }^{\circ}$ Um pousio no Ribeiro de São Thomé, que confronta do Nascente com Manuel Maria Callixto, Poente e Sul com Gualdino Calixto, e Norte com Francisco Moreiral Vale $1.000 \$ 000$ rs.

13. Um pousio no Ribeiro do Maio, que confronta do Nascente, Poente e Norte com valla real e Sul com Jose Trindade. Vale $400 \$ 000$ rs.

14. ${ }^{\circ}$ Um pousio no Ribeiro da Lagôa que confronta de todos os lados com valla real. Vale $1.000 \$ 000 \mathrm{rs}$.

15. Um pinhal nas Canadas que confronta do Poente com Manuel Maria Callixto, Norte com valla real e Sul com Francisco Moreira. Vale 50\$000 rs.

$16 .^{\circ}$ Um pinhal no Mont'alvo e Bemfeita que confronta do Nascente com José Cunha, e Poente com Luis Moreira. Vale $1.000 \$ 000$ rs.

17. Um pousio nas Camarneiras que confronta do Nascente com Manuel Jorge; Poente com Manoel Bandeira, Norte com caminho publico e Sul com valla real. Vale $100 \$ 000$ rs.

18. ${ }^{\circ}$ Um pinhal no Martello, limite da Ermida que confronta do Nascente com José Vinagre; Poente com Manoel Francisco Serra; Norte com João Domingos Louro, e Sul com José da Silva Valente. Vale $50 \$ 000$ rs.

19. Um pinhal no Cabeço da Malva que confronta do Nascente e Poente com João Canadas; Norte com Joaquim Carlos e Sul com Manoel Domingos Louro. Vale $50 \$ 000$ rs.

$200^{\circ}$ Um pousio em S. Thomé que confronta do Poente com Luiz Bica, Norte com Manoel Ferreira e Sul com Antonio Tavares. Vale 200\$000 rs.

21. Um pinhal no Mont'alvo, que confronta do Nascente e Poente com terreno baldio; Norte com Manoel Fixe e Sul com José Balseiro, valor $50 \$ 000$ rs.

$O$ encarregado da inventariação dos baldios

Eduardo da Silva Vieira

O existente na rep. de Fazenda tem a data de 3 d'outubro de 1888.

(A.U.C.: G.C., «Baldios 1884-1894», 15)

7

Oficio do encarregado do inventário para o Secretário Geral do Distrito de Coimbra (19 de Outubro de 1888)

$$
\text { Il. }{ }^{\mathrm{mo}} \text { e Ex. }{ }^{\mathrm{mo}} \text { Snr: }
$$

Em resposta ao officio de V. E. com data de 11 do corrente mes tenho a dizer que a inclusa relação dos baldios do concelho de Mira não contêm os baldios usurpados nos ultimos trinta annos. Neșsa relação estão descriptos sómente os baldios de que a camara está de posse. 
Quasi todos os proprietarios que teem terrenos seus a confrontar com esses baldios, ainda não usurpados, se teem apossado de terrenos pertencentes a esses mesmos baldios. E a parte que elles teem usurpado é difficil demarcar-se porque todos teem interesse em occultar a verdade, incluindo a propria camara.

Deus guarde a V. E. ${ }^{\mathrm{a}}$

Coimbra 19 de Outubro de 1888

Il. mo e Ex.mo Snr. Secretario Geral do Distrito de Coimbra

O encarregado da inventariação dos baldios

Eduardo da Silva Vieira

(A.U.C.: G.C., «Baldios 1884-1894», 15)

Oficio do Administrador do concelho de Mira

enviado ao Governador Civil de Coimbra

(16 de Agosto de 1889)

Il. ${ }^{\text {mo }}$ e Ex. ${ }^{\text {mo }}$ Snr.

A deliberação ultimamente tomada pelo Governo de vender parte dos baldios municipaes d'este concelho, pos n'uma excitação indiscritivel os moradores desta circunscripção administrativa, e devo dizer a V. Ex. ${ }^{a}$, com a devida franqueza, que receio e muito, que por aquelle facto seja gravemente alterada a tranquilidade publica.

Estes povos são fanaticos pelos baldios municipaes, facilmente acreditam que a venda d'elles é uma expoliação que o Governo lhe quer fazer, e os inimigos do Governo, e com especialidade os empregados do Correio, que todos se tem arvorado em propagadores das ideias mais subversivas, chamão os povos á revolta, e indicam-lhes como promotores da venda dos baldios, e consequentemente como os maiores inimigos as pessôas que n'esta localidade, prestam apoio ao Governo.

Repito, pois, a V. Ex. ${ }^{\text {a }}$ receio e muito que pelo facto da venda dos baldios seja gravemente alterada a tranquilidade publica, e creio que o unico meio de obstar $a$ isto é retirar immediatamente da praça aquella venda.

Ja n'este sentido a Câmara Municipal d'este concelho representou ao Governo, mas, porque qualquer providencia do Governo pode demorar-se, parecia-me conveniente que ao escrivão da Fazenda daqui fosse dada immediatamente ordem para não affixar os editais respectivos, que elle ainda não affixou.

Deus guarde a V. Ex. ${ }^{a}$

Mira 16 d'Agosto de 1889

Il. ${ }^{\text {mo }}$ e Ex. ${ }^{\text {mo }}$ Snr. Governador Civil de Coimbra

(A.U.C.: G.C., «Baldios 1884-1894», 16) 


\section{Representação da Câmara de Mira ao Rei (13 de Agosto de 1889)}

Senhor, a Camara Municipal do concelho de Mira surprehendida hontem, com a terrivel noticia de que fora annunciada a venda em praça para o dia trinta e um do corrente mez de parte dos baldios e matas municipaes d'este concelho, vem mui respeitosamente, perante Vossa Magestade pedir que se suspenda immediatamente a venda d'aquelles bens pelos seguintes fundamentos: $10^{\circ}$ Lavra nos povos d'estes concelhos um descontentamento geral que augmenta de momento a momento, pela notícia de que no dia trinta e um do corrente mez se vendem no Governo Civil de Coimbra parte dos baldios e matas municipaes d'esta circunscripção administrativa - facto que pode dar em resultado um levantamento geral pela excitação em que está o povo. 2. ${ }^{\circ}$ Porque os baldios e matas municipaes são absolutamente necessarios para estes povos pois que é d'elles que se extrahem os adubos ou estrumes para a cultura das propriedades e estas nada produzem sem estrumes, por serem arenosas, d'una aridez extraordinaria e safaras; e é das matas que o povo se surte de lenha, e é nos baldios que apascenta os seus gados. A agricultura do concelho de Mira definha completamente sem os baldios e matas. $3 .^{\circ}$ Porque o povo não tolera que lhe vendam os baldios e matas, considera-os como propriedade sua, julga que essa venda é uma verdadeira uzurpação; e não ha meios de o convencer de que o producto da venda d'elles reverte em proveito do Municipio. Ha muito tempo que os povos d'aqui receiam que lhes vendam os baldios e matas e crea Vossa Magestade que aquella venda é uma verdadeira calamidade para este concelho e dá logar a um levantamento. É pois absolutamente necessario suster a venda annunciada e conceder á camara d'este concelho ordem para aforar em praça publica alguns bocados de terrenos baldios que não forem necessarios para logradouro commun, e que, oppurttamente (sic) esta corporação designar. É isto uma garantia da ordem publica, porque os povos d'este concelho, em negocio de baldios só tolera (sic) que a camara os afore ou devida. Escuza pessoa alguma d'aqui ou de fora, tentar tractar em Mira de qualquer assumpto, respeitante à venda dos baldios e matas porque o povo não th'o tolera - corre-os e enxota-os e só consente que a Camara os administre ou afore. A camara - Real Senhor - espera que Vossa Magestade tera na devida consideração este importante assumpto que attenderá o seu justo pedido, e assim: Pede a Vossa Magestade se digne, pelo Ministério da Fazenda mandar immediatamente suspender a venda annunciada dos baldios e matas municipaes d'este concelho e conceder á camara ordem para aforar em praça aquelles bocados de terrenos que se designarem a seu tempo, por serem dispensados do logradouro commum.

E.R.Mê Mira em sessão da camara de 15 de Agosto de 1889.

O Presidente João Maria Ribeiro Calisto

Cópia da sessão extraordinária de 15-Agosto-1889

(A.U.C.: G.C., maço «Baldios 1884-1894», 16-1) 